\title{
LASERSKI SNIMAK TRSATSKOG KAŠTELA KAO DIO STRATEGIJE OČUVANJA KULTURNE BAŠTINE RIJEKE
}

\section{LASER SCANNING OF TRSAT CASTLE AS PART OF PRESERVATION STRATEGY OF RIJEKA CULTURAL HERITAGE}

\author{
Iva Mrak*, Nana Palinić ${ }^{*}$, Cela Matan*
}

\begin{abstract}
Sažetak
Kaštel (Gradina) Trsat je jedan od najpoznatijih objekata graditeljske baštine u Primorskogoranskoj županiji. U svrhu projekta obnove, Grad Rijeka je 2015. godine naručio snimak kompleksa (ukupno skoro $8000 \mathrm{~m}^{2}$ ). Za izradu snimka korištena je laboratorijska oprema Sveučilišta u Rijeci. Cilj rada je prikazati proces snimka, dati analizu mogućnosti kombiniranja laserskog snimka s drugim suvremenim metodama (snimanje bespilotnom letjelicom, fotomodeliranje), usporediti rezultate snimka $s$ postojećim snimkama kompleksa, utvrditi nove podatke o kompleksu te provesti diskusiju o rezultatima i važnosti koje ovakvo kompleksno snimanje može imati za očuvanje kulturne baštine.
\end{abstract}

Ključne riječi: Gradina Trsat, Kaštel Trsat, lasersko snimanje, snimak postojećeg stanja

\begin{abstract}
Trsat castle is one of the most famous heritage elements in Primorsko-goranska County. In 2015, as part of the renewal design, the City of Rijeka has commissioned the survey of the complex (almost $8000 \mathrm{~m}^{2}$ ). The survey was done using the laboratory equipment of University of Rijeka. The aim of the paper is to illustrate the survey process, to analyze the possibility of combining laser scanning with other contemporary methods (drone survey, photo-modelling...), as well as to compare the results of the survey with the previous surveys of the complex, and to determine new data about the complex and discuss the results, especially the importance of such a complex survey for cultural heritage preservation.
\end{abstract}

Key words: Gradina Trsat, Trsat Castle, laser scanning, survey of extant

\footnotetext{
* Sveučilište u Rijeci, Građevinski fakultet, Radmile Matejčić 3, 51000 Rijeka E-mail: \{iva.mrak, nana.palinic, cela.matan\}@gradri.uniri.hr
} 


\section{Uvod}

Kaštel (Gradina) Trsat je jedan od najpoznatijih objekata graditeljske baštine u Primorsko-goranskoj županiji te je pojedinačno zaštićeno nepokretno kulturno dobro, upisano u Registar kulturnih dobara Republike Hrvatske pod oznakom Z-342. Građen je u više faza, od rimskog doba, kroz srednji vijek, kada je u posjedu obitelji Frankopan (1225.-1670.), potom u posjedu Ugarske komore i bakarskog municipija.

Utvrda na Trsatu vjerojatno je postojala i u prapovijesti, a u antičko doba, na Peuthingerianovoj mapi zabilježene su dvije odvojene kule [1]. U periodu prije 13. stoljeća čini se da je utvrda napuštena [2], a u 13. stoljeću gradi se veća utvrda na mjestu već postojeće [3]. 1750. potres oštećuje gradinu (posebno više dijelove i gotovo sve osim osnovnih zidova) koja je zbog toga napuštena [3] te zapuštena. 1826. g. Kaštel Trsat kupuje grof Laval Nugent, koji ga obnavlja u neogotičkom i klasicističkom duhu po projektu Giacoma Paronuzzija te u njemu smješta svoju izuzetno veliku i bogatu zbirku umjetnina (prvenstveno, ali ne samo starorimske skulpture, starogrčke fragmente, etrurske i egipatske skulpture, reljefe, arhitektonske elemente, koje dobiva kao dar od Kraljevine dvije Sicilije, s iskopa u Puli, zatim Napoleonov stup iz Marenga), a koju dodatno nadograđuje njegov nasljednik). U ulaznom dijelu Kaštela 1870. g. izgrađena je rezidencija obitelji Nugent Decrevi u kojoj danas ima sjedište udruga Gradska glazba Trsat. $[3,4,5,6]$

U 20. stoljeću rađeni su zahvati adaptacije (posebno krajem 50-ih), a u više navrata rađeni su i djelomični snimci postojećeg stanja. Zahvati su manjim dijelom dokumentirani. Osim toga, intervencijama, posebno fugiranjem i nanošenjem žbuke, velikim je dijelom onemogućeno praćenje vremenskog slijeda gradnje, što je dodatno spriječeno i otežanim ili nemogućim pristupom različitim dijelovima kompleksa.

U svrhu izrade novog projekta obnove, Grad Rijeka je 2015. godine od Građevinskog fakulteta naručio snimak kompleksa, a područje obuhvata je uključivalo: Kaštel (Gradinu) Trsat (unutrašnji i vanjski dio, $548 \mathrm{~m}^{2}, 510$ $\left.\mathrm{m}^{2}\right)$, park $\left(5341 \mathrm{~m}^{2}\right)$, pristupni put $\left(794 \mathrm{~m}^{2}\right)$ te bivšu rezidenciju Nugent Decrevi $\left(778 \mathrm{~m}^{2}\right)$ (Slika 1). Ukupna površina obuhvaćena snimkom je $7971 \mathrm{~m}^{2}$. Za izradu snimka korištena je laboratorijska oprema Sveučilišta u Rijeci, nabavljene putem projekta RISK. Izrada snimka [7] trajala je od rujna 2015. do kolovoza 2016. Snimak je bio i dio Istraživačkog projekta „Arhitektura Rijeke i riječke regije kao razvojni resurs" (voditeljica projekta izv. prof. dr. sc. Nana Palinić, dipl. ing. arh.), a služio je i za izradu Konzervatorske studije [8]. Snimak i Konzervatorska studija dio su dokumentacije za objekt Gradine Trsat predviđene Strategijom kulturnog razvitka Grada Rijeke 2013.-2020. [9] u kojoj se kultura smatra razvojnim elementom Grada Rijeke, a u dijelu Strategije „Zaštita materijalne kulturne 
baštine" navodi se da je Gradina Trsat jedna od najvažnijih točaka kulturne baštine čije se stanje smatra nedovoljno održavano, zbog čega se planira izrada dokumenata uređenja i upravljanja.

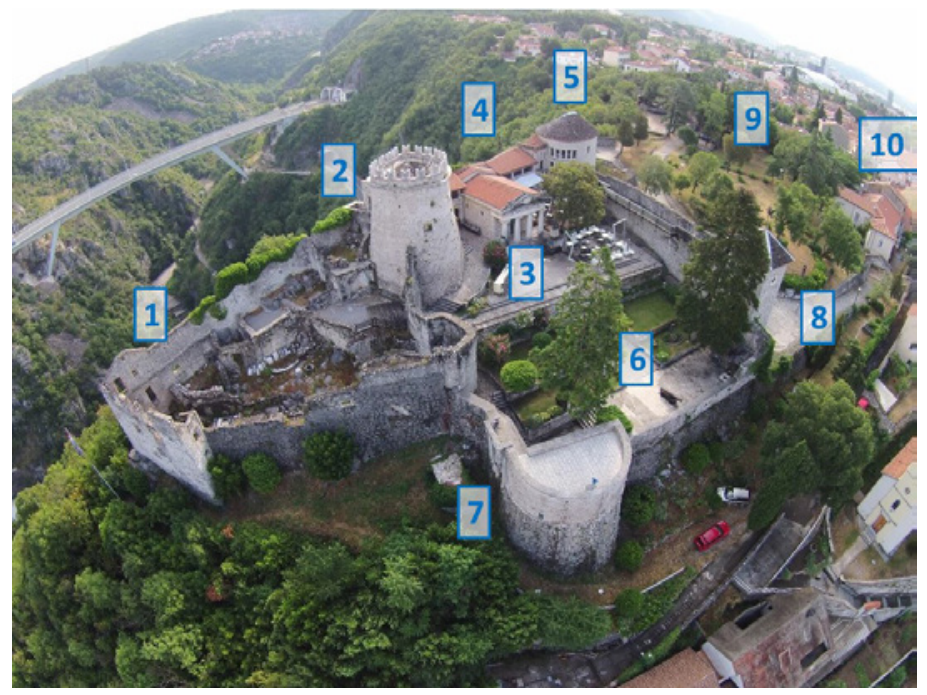

Slika 1. Kaštel Trsat s parkom i rezidencijom Nugent Decrevi. Lijevo: Zapadni/ stambeni dio (1); centralno: Rimska kula (2), Mauzolej (3), sjeverni dio (4), Sjeveroistočna kula (5), dvorište (6), Južna kula (7), Ulazna kula (8); desno: park (9), rezidencija (uz prilaz 10) [7]

\section{Ciljevi rada, materijali i metodologija}

Ciljevi snimka obuhvaćali su izvedbu snimka postojećeg stanja 3D laserskim snimanjem, ali i kombiniranje ove metode s drugim suvremenim metodama (poput snimanja bespilotnom letjelicom, fotomodeliranja). Cilj ovog rada je prikaz procesa izrade snimka, analiza rezultata snimka korištenjem suvremenih metoda, usporedba rezultata snimka s postojećim snimkama kompleksa (npr. gdje suvremeni snimak izuzetno poboljšava rezultate, gdje klasični snimak također daje dobre rezultate, a gdje možda još nemamo adekvatnih načina snimanja), utvrđivanje novih podataka koji se ranije nisu mogli prikupiti (npr. zbog nepristupačnosti terena). Rad sadrži i diskusiju o rezultatima te, na kraju, zaključke.

Postojeća dokumentacija uključivala je katastarski plan, ortofoto digitalni snimak te snimke postojećeg stanja izrađene 1956. [10], 1986. [11] i 2001. [12] godine. Ovi snimci rađeni su tradicionalnim metodama te su korišteni kao podloga za organizaciju rada. Proces snimka obuhvaćao je više faza: geodetsku izmjeru totalnom stanicom i GPS uređajem, snimanje 3D laserskim skenerom, snimanje bespilotnom letjelicom, spajanje, 
georeferenciranje oblaka točaka i verifikaciju podataka, kreiranje 3D modela u obliku oblaka točaka (point cloud), kreiranje Structure from Motion (u daljnjem tekstu: SfM) modela, kreiranje podloga za crtanje kombinacijom metoda (3D, SfM fotomodeliranje, klasično mjerenje), izradu Arhitektonskog snimka postojećeg stanja, vizualizaciju u 3D tehnici putem oblaka točaka kao nositelja podataka.

Nakon izrade snimka postavilo se pitanje razlike između postojećih snimaka i novog snimka te pitanja o važnosti suvremenih tehnologija snimka u očuvanju graditeljske baštine. Zbog toga su napravljene analize i usporedbe postojećih snimaka i najnovijeg snimka te doneseni zaključci o važnosti i mogućnosti novih tehnologija u izradi snimka. Izradom analitičkih komparativnih tablica uspoređeni su obuhvati i sadržaj nacrta različitih snimaka te su analizirani pojedini elementi u svakom pojedinom nacrtu (izvadak je prikazan u Tablici 1), a na kraju je izvršena i komparacija prikaza i podataka u različitim snimcima.

\section{Izrada snimka postojećeg stanja i analiza kombinacija tehnologija u izradi snimka}

\subsection{Vrste snimka}

Osnovne sastavnice snimka su imitacija oblika i mjerenje. Grafički prikaz i odabrane karakteristike za prikazivanje te prijevod objekata $\mathrm{u}$ grafički i/ili prostorni model ovise o namjeni snimka, odnosno snimak nije neutralan. Na značajke snimka utječu razni elementi kao što su ljudska preciznost, umor, preciznost instrumenta, poznavanje elemenata koji su potrebni za prepoznavanje karakteristika objekta... Iz ovih značajki snimka proizlazi da metode kod kojih je izražen utjecaj ljudskog faktora (znanja i fizičkih sposobnosti) mogu vjerojatno puno značajnije varirati od onih metoda gdje su ovi utjecaji smanjeni. Pri snimku se grafičkom prikazu na neki način (pismeno na papiru, smještajem elementa u virtualni prostor...) dodjeljuju vrijednosti odabranim karakteristikama (npr. dimenzije, visine). Ove mjere imaju određenu preciznost (ili grešku) koja ovisi o metodama, instrumentima i osobama koje vrše snimak [13].

Osnovne kategorije snimka su tradicionalni snimak gdje je mjerni instrument $\mathrm{u}$ kontaktu sa objektom i indirektni snimak gdje su mjerni instrumenti udaljeni od objekta [13,14]. Tradicionalni snimak se prvenstveno ostvaruje korištenjem metra, mjernih vrpci i različitih pomagala kao što su ravnala, kutomjeri, Burtonov češalj, nivelir, uže... U kategoriju indirektnog snimka spadaju snimanje totalnom stanicom, 3D lasersko snimanje, fotogrametrija i fotomodeliranje. Pritom je lasersko skeniranje karakteristično i po tome što je aktivno, odnosno uređaj aktivno šalje zraku koju očitava, dok fotografski aparati, koji se koriste pri fotogrametriji i fotomodeliranju, koriste postojeću svjetlost [15]. 
3D laserski snimak se dobiva očitanjem pozicije točaka na objektu tako što instrument šalje lasersku zraku te očitava vrijeme i kut povratka. Što su gušće očitane točke, to je snimak kvalitetniji, ali i tehnički, vremenski i financijski zahtjevniji. U snimku tradicionalnim instrumentima preciznost ovisi o mjerilu prikaza, dok oblak točaka dobiven laserskim snimkom daje mogućnost jednake preciznosti bez obzira na približavanje ili udaljavanje od modela, no s druge strane ovisi o značajkama tehnologije koja se primjenjuje (preciznost instrumenta kojim se snima, mogućnosti radnih stanica gdje se podaci obrađuju i pregledavaju...).

Fotogrametrija je postupak snimka tradicionalno iz stereo para fotografija iz precizno kalibriranog objektiva (i posebno preciznih karakteristika) i na određenoj udaljenosti. Ova tehnika snimka je razvijena polovicom 19. stoljeća (Aimé Laussedat, Francuska). Izračun dimenzija fizičkih elemenata se u ovoj tehnici izrađuje na temelju mjera iz fotografija i poznavanja karakteristika fotoaparata (leća) i udaljenosti [16,17].

$\mathrm{U}$ fotogrametriji se fotografije izuzetne preciznosti postavljaju $u$ pravilne prostorne odnose na način da se izbjegavaju deformacije. Na taj način prenose se (odnosno zadržavaju) velike količine podataka (koje ovise o rezoluciji fotografija - o stanju na površinama, prekidima, materijalima, bojama...), ali se i daju prostorne informacije o smještaju elemenata u prostoru. Tradicionalno se ova metoda tijekom 20. st. izvodila korištenjem fotoaparata s objektivima koji su osiguravali malu deformaciju (izuzetno skupa oprema) te su se fotografije posebnom opremom spajale u jedinstven snimak, a definirala se obično jedna ploha objekta, koristeći po dva fotoaparata, odnosno izvodeći stereofotogrametriju [16].

Danas se metoda fotogrametrije sve više poistovjećuje sa SfM metodom za koju postoji niz softwarea kojima se ove fotografije mogu spojiti u plohu ili volumen. Koncept SfM metode se bazira na ljudskoj percepciji, odnosno sposobnosti čovjeka da formira dojam prostorne strukture (ali i kretanja, smjera te brzine) iz percepcije (prvenstveno, ali ne samo, vizualne). Pri izradi SfM modela koriste se fotografije iz raznih kutova (pogleda) koje software preklapa, a svaki dio objekta treba biti vidljiv na najmanje 3 fotografije. SfM modeliranje omogućava formiranje virtualnog volumena iz fotografija, ali istovremeno i sami proizvođači softwarea koriste termin fotomodeliranje, a ne fotogrametrija, ističući mogućnost 3D modeliranja na bazi fotografija, a ne preciznost (koja često nije niti moguća, a osnovna je karakteristika klasične fotogrametrije). Usporedno se u znanstvenim člancima pojavljuju i dalje termini fotogrametrija, ali i fotogrametrijsko modeliranje [17] - ističući da se ipak zamjećuje razlika u odnosu na klasičnu fotogrametriju (te da su okrenuti različitim profilima korisnika) [18] ili da neki softwarei omogućuju obje funkcije, a da je za dobar snimak ključno poznavanje karakteristika metoda i tehnika snimaka te samog objekta.

Rezultat 3D laserskog snimka i fotomodeliranja su oblaci točaka. Od 3D oblaka točaka također se putem izrade 2D ili 3D modela interpretiraju 
informacije jer sami oblak točaka nije ujedno i model (iako može djelovati tako, a posebno to vrijedi za SfM) jer točke nisu međusobno povezane (između točaka se mogu nalaziti izvori informacija koje smo „preskočili“, a što velikim dijelom ovisi o rezoluciji).

\subsection{Snimanje Kaštela Trsat}

Lasersko snimanje Kaštela Trsat obavljeno je terestričkim panoramskim laserskim skenerom (godina nabave 2014.). Skener sadrži GPS uređaj, kompas, inklinometar i altimetar, integriranu kameru u boji i ima mogućnost automatske prilagodbe osvjetljenja. Postupak snimanja je uključivao: izradu plana snimanja, snimanje 3D skenerom i izmjere na terenu, registraciju podataka snimanja na računalu u softwareu proizvođača laserskog skenera, obradu i provjeru podataka u istom softwareu, dodatna snimanja zbog nadopunjavanja podataka, eksportiranje oblaka točaka, georeferenciranje i spajanje oblaka točaka u drugom softwareu u slobodnom pristupu. Jedinstveni oblak točaka se kasnije koristio za vizualizaciju, mjerenje i prezentaciju te za kreiranje podloga za crtanje nacrta.

Laserska snimanja rađena su u više navrata u razdoblju od listopada 2015. do svibnja 2016. Snimanje vanjskih prostora unutar Kaštela bilo je ograničeno na periode u kojima je Kaštel zatvoren za posjetitelje. Kod ostalih otvorenih prostora nije bilo moguće ograničiti kretanje prolaznika ili druge promjene uvjeta (kretanje životinja, pomicanje lišća) tijekom snimanja te su snimci često morali biti rađeni više puta. Također, nije bilo moguće snimati kod kišnog ili vjetrovitog vremena, a niti kod prevelike insolacije. Snimanje unutarnjih prostora bilo je ograničeno zbog činjenice da se namještaj tijekom snimanja nije uklonio. Kod svakog stajališta skenera dobiven je jedan snimak te niz fotografija jer nakon snimanja prostora skener vrši i fotografiranje. Dobivene fotografije važne su radi dodjeljivanja boje točkama u oblaku. Prostori u kojima nema dovoljno svjetlosti snimljeni su bez fotografiranja. Primjer ovakvog snimka je 3D oblak točaka tavana ex Rezidencije Nugent Decrevi (koja je bila sastavni dio ovog snimka, ali se nalazi izvan osnovnog obuhvata kompleksa Gradine, a bila je predmet snimka i diplomskoga rada [19] koji je također bio dio istog istraživačkog projekta).

Kako bi se dobivene informacije, odnosno oblak točaka mogao konzultirati na otvorenoj platformi, napravljen je objedinjeni georeferencirani oblak točaka u softwareu u slobodnom pristupu. Formirani oblak točaka eksportiran je iz softwarea za obradu oblaka točaka laserskog skenera te podijeljen na više oblaka $s$ horizontalnim razmakom od $0,5 \mathrm{~cm}$. U softwareu u slobodnom pristupu učitani su svi oblaci točaka koje se, prema potrebi, može uključivati ili isključivati. Apsolutne visinske kote (podova, stropova, stepenica, krova...) dobivene su očitavanjem iz ovog cjelovitog oblaka točaka. Ovaj korak je jedna od najvažnijih značajki ovog snimka u odnosu na tradicionalne snimke jer 
omogućava precizno određivanje visinskih kota i na mjestima koja nisu dostupna ili su teško dostupna te omogućuje očitanje i zadržavanje brojnih informacija uvjetovanih veličinom obuhvata i geometrijom kompleksa, kao i usporedbu pozicije i dimenzija različitih elemenata međusobno. Slika 2 prikazuje oblak točaka sjevernog zida s kojeg se putem softwarea mogu očitati koordinate (npr. visina) te dužina povijesnih tragova koji nisu fizički pristupačni i koji su u ovom snimku po prvi puta dokumentirani na crtežu i fotografijama, a važni su za utvrđivanje mogućih kota etaža zgrade te evolucije kompleksa.

Međutim, pri spajanju dijelova snimka, iako se rad odvijao na radnoj stanici s posebnom grafičkom karticom, a posebno radi korištenja i od strane drugih korisnika (npr. naručitelja) primijećeno je da je radi pokretanja modela cijelog kompleksa bilo potrebno smanjiti rezoluciju, što je u nekim dijelovima dovelo do slabije razlučivosti. Zbog toga je dodan SfM model, koji se također pregledava kao dodatni sloj. Naime, uz lasersko snimanje kompleks je sniman i bespilotnom letjelicom (te klasičnim fotoaparatom), a fotografije koje su tako dobivene značajne su jer se na ovaj način može dobiti uvid u dijelove kompleksa koji nisu (jednostavno) dostupni (zbog veličine kompleksa, fizičke nepristupačnosti, financijske zahtjevnosti...).

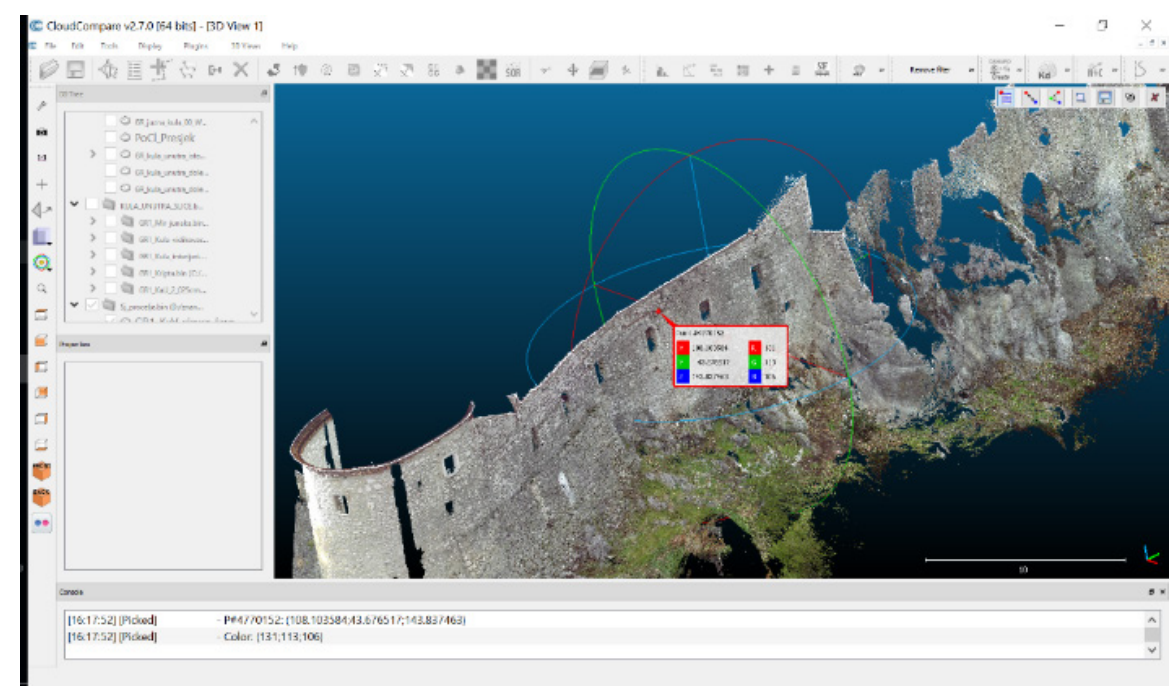

Slika 2. Rad sa softwareom u slobodnom pristupu - primjer očitavanja prostornih podataka sa sjevernog zida

Tijekom rada ipak je primijećeno da SfM ne odražava ispravnu geometriju kompleksa, već razvlači teksturu dajući nerealni oblik otvorima i teksturi materijala, što je posebno problematično jer djeluje realističnije nego oblak točaka dobiven laserskim snimanjem koji, međutim, odražava 
ispravnu geometriju i dimenzije te je na kraju snimak (nacrti) rađen gotovo isključivo prema laserskom snimanju te djelomično preklapanjem fotografija razvučenih u pravilni geometrijski položaj. Osim mjera dobivenim laserskim snimanjem, točnost mjerenja (npr. parapeti, dimenzije otvora, stolarije, visine i širine stuba) provjerena je klasičnim metodama uz pomoć metra, laserskog metra i mjerne vrpce. Na snimcima su u aplikacijama za tehničko crtanje i obradu rasterskih podloga iscrtani, osim osnovnih oblika i dimenzija kompleksa i što je moguće detaljnije prekidi u konstrukciji, promjene u materijalima, oblici građevinskih elemenata, materijali i svi ostali vidljivi tragovi.

\section{Postojeći snimci i obuhvati snimaka}

Povijesno je Kaštel Trsat prikazan na nekim poznatim prikazima Rijeke. Na prikazima iz 16. stoljeća (Angielini, Klobučarić), na Zapadnom/ stambenom dijelu se prepoznaje niz prozora (iako samo po dva, odnosno jedan red), a sjeverni dio djeluje viši (te također ima red prozora). Prepoznaje se Južna kula, visine kao i danas te viša Rimska kula. Na prvom prikazu se prepoznaje zgrada na poziciji današnjeg istočnog zida, a na drugom prikazu se prepoznaje istočni zid dok se Ulazna i Sjeveroistočna kula mogu prepoznati kao manje kule. Na Valvasorovom prikazu (1689.) se prepoznaju Zapadni/stambeni dio s 3 etaže, ulazna Zapadna kula (danas jedva prepoznatljivi ostaci) te veće Južna i Rimska kula, dok su današnje istočna Ulazna kula i Sjeveroistočna kula prikazane kao manje. Prozori se nalaze i u dijelu od Južne kule prema zapadu, dok se prema istoku ne mogu razaznati. Na prikazu Dolazak cara Karla VI. u Rijeku (nepoznati autor, 1728.) slično su prikazani Zapadni/stambeni dio (s 3 etaže), ulazna Zapadna kula, Južna i Rimska kula, a istočna Ulazna i Sjeveroistočna kula su prikazane kao manje. S obje strane Južne kule vide se prozorski otvori. Kule su slične visine, osim Rimske koja je nešto viša. Iz ovih prikaza teško je zaključiti kakav je bio stvarni kompleks u određeno doba jer je na starijim prikazima teško razlučiti što je stvarna karakteristika objekta, a što stilsko obilježje (npr. redovi prozora, visina kula, objekti ili zid u južnom i istočnom dijelu, visine kula bliže sadašnjim...) Osim toga, iz ovih prikaza nije moguće utvrditi unutrašnju prostornu organizaciju i komunikaciju unutar kompleksa. Također, prikazi prikazuju kompleks s južne strane (pogled na Rijeku s mora). Osim toga, više povijesnih prikaza uopće ne prikazuje sličnu tipologiju kompleksa (npr. Matthäus Merian st., St. Veit am Flaum, 1649.), a neki prikazi prikazuju Nugentovu adaptaciju, ali s proporcijama drugačijim u odnosu na stvarne (npr. Manzoni, 1837.) [4]. Klasični tehnički snimci su rađeni u 20. stoljeću. 
Snimak iz 1956. g. [10] (u daljnjem tekstu: snimak A) rađen je prije izrade Konzervatorske studije i projekta rekonstrukcije i adaptacije užeg prostora Kaštela iz 1958. Snimak sadrži situaciju u 1:200, nacrte u 1:100 (tlocrt - situacija kompleksa na ulaznoj razini, razini Mauzoleja i krovnih ploha), nacrte u 1:50 (Mauzolej, kripta, Ulazna kula, Istočni zid, Sjeveroistočna kula, zid prema Rimskoj kuli, pogled na Mauzolej, ulazna vrata), nacrte u 1:20 (detalji s fasade ulazne kule) te projekt uređenja kompleksa (tlocrt). Snimak iz 1986. godine [11] (u daljnjem tekstu: snimak B) sadrži situaciju u 1:500, nacrte snimka u 1:50 (Mauzolej, Sjeveroistočna kula i sjeverni ophod) te projekt uređenja (u istim prostorima). Snimak iz 2001. godine [12] (u daljnjem tekstu: snimak C) rađen je prema snimku 1986. godine, uz nadopune. Sadrži situaciju u 1:500 te nacrte u 1:50 (tlocrti na kotama 134, 139, 142, 144, 151, 6 presjeka kompleksa, 3 pročelja kompleksa), nacrte u 1:20 (detalji hrama, rozete ulazne kule...). Parcijalni snimci rađeni su i prilikom radova na sanaciji i konzervaciji 2002. godine (Danko Grgić) te 2008. (Egon Lokošek).

Svi ovi snimci izrađeni su klasičnom metodom, direktnim mjerenjem metrom i mjernom vrpcom na građevini, uz rekonstrukcije pojedinih dijelova temeljem fotografija. S obzirom na korištenu metodu mjerenja, snimci su napravljeni kvalitetno i pregledno te pokazuju kako je za njihovu izradu bio potreban velik rad na terenskom mjerenju i crtanju. Osobito je kvalitetan snimak iz 1958. godine, pogotovo ako se uzme u obzir zapušteno stanje u kakvom se Kaštel Trsat u to doba nalazio.

Postojeći snimci daju nacrte različitih dijelova kompleksa u različitim mjerilima na papirnatoj podlozi. Podloge dobivene novim snimkom [7] (iz 2016., u daljnjem tekstu: snimak D) su nacrti dijelova kompleksa u različitim mjerilima (npr. 1:100 ili 1:50, 1:20) na papirnatoj podlozi i pdf formatu, u mjerilu 1:1 u dwg datoteci, oblak točaka napravljen iz 3D laserskog snimanja, 3D model napravljen SfM tehnikom iz fotografija snimljenih bespilotnom letjelicom te velika količina fotografija napravljena bespilotnom letjelicom i fotoaparatom.

Radi usporedbe su utvrđeni obuhvat i sadržaj različitih snimaka, a zatim su napravljene analitičko komparativne tablice po dijelovima (zonama) kompleksa u kojima se preciznije utvrdila razlika između prikaza i elemenata različitih snimaka. Prema ovim analizama utvrđena su osnovna područja novih podataka (i novog obuhvata), osnovnih razlika u podacima (prikazima) te doneseni zaključci o tehnikama i važnosti snimka. Posebno je zanimljivo pratiti količinu, vjerodostojnost i važnost informacija s obzirom na mjerilo te utvrditi jesu li tehnike snimaka dovoljne kako bi se utvrdile informacije kao što su stratigrafija i faze gradnje. Shematski prikaz obuhvata različitih snimaka prikazan je na Slici 3. Snimci se, osim u tlocrtnom obuhvatu, razlikuju i u prikazima pročelja i presjecima, ponajviše u preciznosti visina, što je posebno analizirano (izvadak je dan u Tablici 1). 


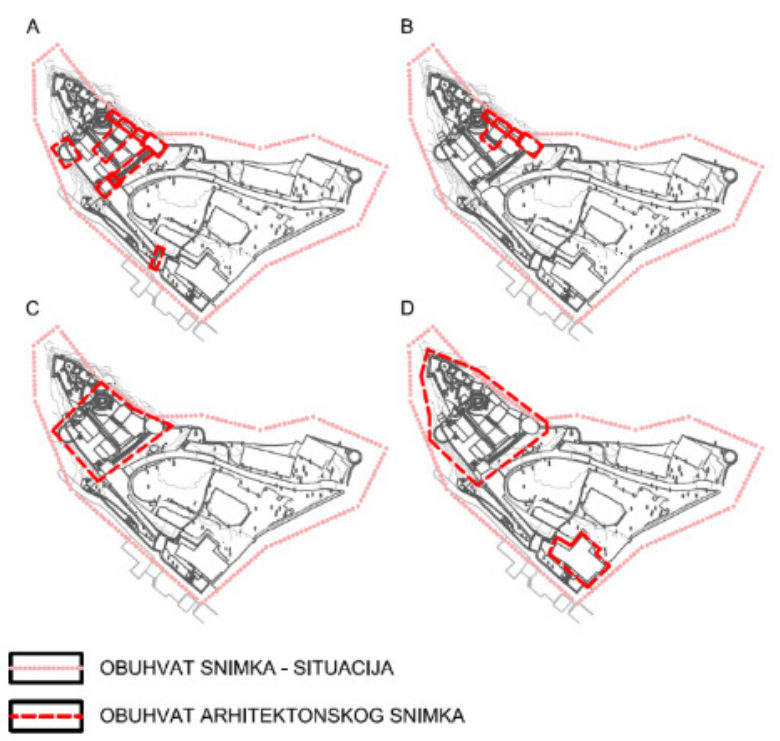

Slika 3. Shematski prikaz obuhvata različitih snimaka

Tablica 1. Analitička tablica snimaka prema prikazanim elementima - izvadak

\begin{tabular}{|l|l|}
\hline Snimak A & Nacrt: Pogled kapelice „Mir Junaka“ \\
& $\begin{array}{l}\text { Prikazani su prilaz Zapadnom dijelu, obrisi Rimske kule, stubište koje uz } \\
\text { Rimsku kulu vodi do 1. kata sjevernog dijela, sjeverni dio, Mauzolej. Kote } \\
\text { Rimske kule su dijelom označene (150,29 m kota ukupne visine, 149,42 } \\
\text { m kota na kojoj počinju prsobrani, 148,75 m, gornja kota vijenca) } \\
\text { Zapadno od Mauzoleja vidimo prizemlje s dva luka; kod istočnog se vidi } \\
\text { kameno ziđe. Iznad vijenca je postavljena ograda kata. Krovište kata nose } \\
\text { dva stupa (uz Rimsku kulu i na poziciji između dva luka prizemlja) te } \\
\text { zidani dio uz Mauzolej. U 2. planu se uočavaju preinake na S zidu. Istočno } \\
\text { od mauzoleja se vide tri luka te četvrti koji je u drugoj ravnini, pred SI } \\
\text { kulom. Visine lukova su kotirane: } 171 \text { cm od kote poda do stope, debljina } \\
\text { luka 23-30 cm; nije kotiran promjer ili visina. 107 je cm od tjemena luka } \\
\text { do donjeg dijela rukohvata. Na katu krov nose dva stupa širine } 21 \mathrm{~cm} \text { i } \\
\text { dio zida prema Mauzoleju i SI kuli na kojem se pojavljuju otvor (vrata), i } \\
\text { iznad toga „tri reda opeka“ te vijenac. Na 2. katu se nastavlja zid stubišta } \\
\text { s jednim pravilnim otvorom i nekoliko nepravilnih oznaka (otvori ili } \\
\text { vjerojatnije oštećenja). Razmaci među stupovima su } 200 \mathrm{~cm}, 190 \mathrm{~cm}, 200 \\
\text { cm. Visina zida stubišta nad krovom 45+30 (otvor)+50+25 dekorativni } \\
\text { vijenac + 45 cm =195 cm. }\end{array}$ \\
\hline Snimak B & Ne daje usporedivi nacrt \\
\hline
\end{tabular}




\begin{tabular}{|c|c|}
\hline Snimak C & $\begin{array}{l}\text { Nacrt: Južno pročelje 1:50 } \\
\text { Nacrt je rađen pod nagibom u odnosu na Mauzolej pa je dio sjevernog } \\
\text { dijela skriven. Vide se dva luka u prizemlju i stup na katu, a zid uz } \\
\text { Mauzolej na katu je oštećen. U istočnom dijelu su prikazana tri luka i } \\
\text { jedan luk ispred SI kule. Na katu se vide dva stupa te stup na kutu zida } \\
\text { prema SI kuli, vrata i manji otvor na zidu stubišta. Na krovištu Sjevernog } \\
\text { dijela se vidi element kao dimnjak. }\end{array}$ \\
\hline Snimak D & $\begin{array}{l}\text { Nacrt: Pročelje Kaštela jug } \\
\text { Dane su visine Rimske kule }(150,62 \text { m kota ukupne visine, } 149,74 \text { m kota } \\
\text { na kojoj počinju prsobrani, 149,05 m gornja kota vijenca). Nagib snimka } \\
\text { je kao u snimku C. } \\
\text { Materijali su detaljno prikazani kao i veličina pojedinih elemenata. } \\
\text { Prikazana su različita krovišta Sjevernog dijela pa i razlike u postavljanju } \\
\text { krovnog pokrova. Mogu se prepoznati krovište uz Rimsku kulu, dva } \\
\text { različita krovišta iza Mauzoleja (jedno s padom prema jugu gornja kota } \\
145,09 \text { m, drugo dvostrešno, kao i krovište Mauzoleja, ali više (kota } \\
144,95 \text { m). Prema istoku se prostire jedno nepravilnije krovište. Prema } \\
\text { SI kuli, na katu, nema vijenca od opeke niti tri reda opeke, otvor prolaza } \\
\text { je definiran ertama, a otvor prozora je mali (puškarnica). Prikazana je } \\
\text { bravarija na otvorima prizemlja. Visine luka: } 184 \mathrm{~cm} \text { od poda do stope } \\
\text { luka, debljina luka } 25 \mathrm{~cm} \text {, a } 102 \mathrm{~cm} \text { je od tjemena luka do donje plohe } \\
\text { rukohvata na katu. Udaljenosti među stupovima su } 180 \mathrm{~cm} \text { i } 190 \mathrm{~cm} \text {. } \\
\text { Prikazana je i krovna ploha prostora stubišta. }\end{array}$ \\
\hline Usporedba & $\begin{array}{l}\text { Snimci A i C ne daju teksturu zida, dok su na snimku D prikazani } \\
\text { materijali. Razlikujemo lukove prizemlja od opeke, kutne elemente zidova } \\
\text { pod lukovima iz većeg kamenja i ispune od manjeg kamenja, linearni } \\
\text { vijenac između dvije etaže i ispunu ograde od sitnijeg ziđa. Iznad toga } \\
\text { su prikazani stupovi koji nose krovište, a vidljivo je da zid uz Mauzolej } \\
\text { završava stupom (na mjestu oštećenja iz snimka C). Između snimka A i } \\
\text { D vidljive su razlike u mjerama elemenata i razmaka, a snimak C ne daje } \\
\text { detaljno usporedive mjere. Sami elementi su u snimcima A i C prikazani } \\
\text { samo u osnovnim linijama, dok se u snimku D može ući u teksturu i } \\
\text { detalje konstruktivnih elemenata jer je baza snimka oblak točaka velike } \\
\text { preciznosti i količine podataka, dok se ručno, tradicionalnim snimkom, } \\
\text { ista količina podataka ne može prenijeti. Snimak A daje pogled s južne } \\
\text { strane elemenata koji se nalaze na višoj razini kompleksa, od Rimske } \\
\text { kule na zapadu (uključujući), do SI kule (uključujući). Snimak B ne daje } \\
\text { usporedive nacrte. } \\
\text { Snimak C daje prikaz Zapadnog dijela (pretpostavka prema fotografijama, } \\
\text { budući da Zapadni dio nije izmjeren osim osnovne geodetske izmjere kao } \\
\text { kod Snimka A) te glavnog dijela zajedno s elementima u drugom planu. } \\
\text { Snimak D daje prikaz cijelog kompleksa sa svim elementima, uključujući i } \\
\text { po prvi puta izmjereni Zapadni dio s elementima u drugom planu. }\end{array}$ \\
\hline
\end{tabular}


Snimci A, C i D obuhvaćaju snimke kompleksa (situaciju) i različitih zona. Snimak B ima najmanji opseg jer se bazira na snimku A te razrađuje rješenje uređenja Mauzoleja i povezanih prostora. Snimak A daje situaciju u 1:200, snimak C u 1:500, a snimak D u 1:500 i 1:200. Snimak D daje i 12 horizontalnih presjeka kroz kompleks i teren koji precizno pozicioniraju sve osnovne elemente u prostoru - gledano tlocrtno, ali i sa aspekta visina i zadržavanja kutova. Snimak D po prvi puta daje detaljan snimak zapadnog (stambenog) dijela kompleksa te sjevernog pročelja (koje je nepristupačno i nije obuhvaćeno prijašnjim snimcima). Snimci C i D daju tlocrte kompleksa na različitim visinama, uključujući i krovne plohe, dok snimak A razrađuje kompleks po različitim elementima kompleksa. Snimci A i D daju i situaciju s tlocrtima na razini mauzoleja i na razini podzemne grobnice (koju snimak C ne daje). Snimak D daje tlocrt zapadnog i središnjeg dijela u visini špilje te tako postavlja ove prostorne elemente u pravilne prostorne odnose. Snimak A daje pročelja elemenata, dok snimci C i D prikazuju cjelovite poglede na kompleks izvana i iznutra (presjeci kompleksa). Dok snimak A ne sadrži nacrt zapadnog pročelja, snimak C sadrži nacrt ovog pročelja, iako nije rađeno detaljno, već samo situacijsko snimanje. Snimak D daje detaljno nacrtano zapadno pročelje koje je i detaljno snimljeno. Snimci A i C sadrže detalje manjeg broja elemenata. Snimci A i B daju i nacrte projekta uređenja.

\section{Rasprava rezultata}

Radi prostornog ograničenja, navest će se samo najznačajniji podaci o prostoru i konstrukciji kompleksa te o karakteristikama snimaka. Na Slici 4 prikazani su osnovni dijelovi kompleksa.

\subsection{Ulazna kula}

Ulazna kula (Slika 5) je od snimka A do snimka D doživjela neke značajne promjene. Prema tlocrtima, od snimka A do snimka C i D, Ulazna kula je doživjela velike preinake u zoni 1 . kata, a posebno je vidljivo da je na zapadnom zidu kule prerađen ulaz i otvoren prozor, kutovi kule $s$ unutrašnje strane su redefinirani, primjetna je razlika u širini otvora prema ophodu (na 2. katu), koja je od snimka A do snimka C povećana. Prema snimcima C i D, zidovi su danas ravniji, dijelom deblji, a vidi se i prozor uz vrata prema dvorištu. Platno oko portala djeluje kao da je dodano naknadno - tanje je (razlika od snimka A do snimaka C i D). Kula u presjeku snimka A nema međukatne konstrukcije (bila je srušena), ali su prelazi etaža dobro vidljivi i označeni (npr. promjena debljine zidova). 


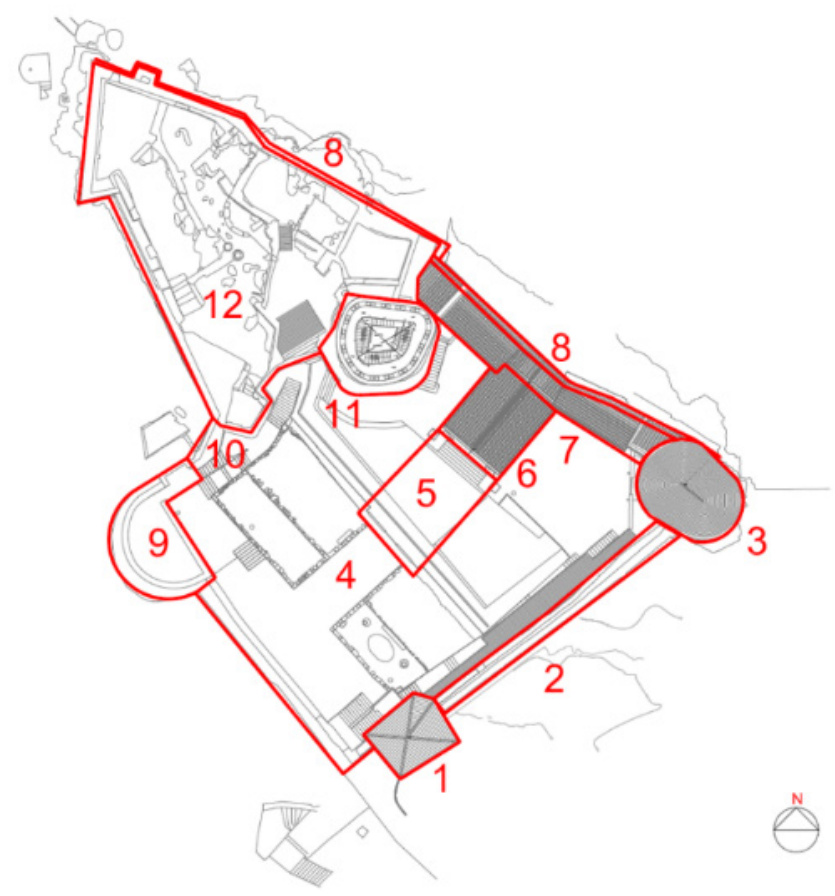

Slika 4. Kompleks Trsatske gradine/kaštela (1 - Ulazna kula, 2 - Istočni zid, 3 Sjeveroistočna kula, 4 - dvorište (u dvije razine), 5 - prostor kripte (ispod gornje razine terena), koji se prostire i ispod 6, ispod 5 je spilja, 6 - Mauzolej, 7 - Sjeverni dio kompleksa, 8 - Sjeverni zid, 9 - Južna kula, 10 - Zapadni ulaz, 11 - Rimska kula, 12 - Zapadni/stambeni dio). Rezidencija Nugent Decrevi se nalazi izvan kompleksa, jugoistočno, i odvojena je parkom.
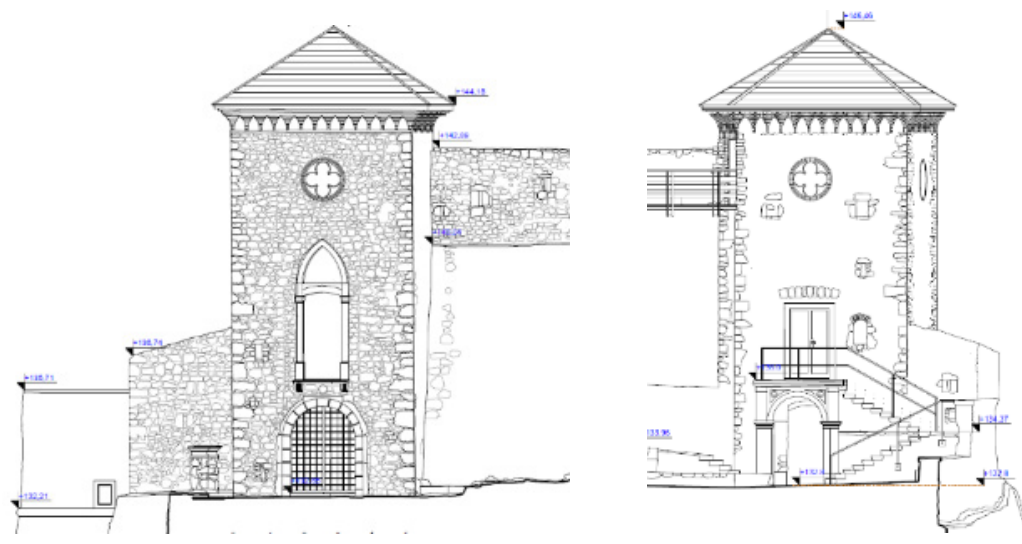

Slika 5. Ulazna kula - lijevo: istočno pročelje, desno: zapadno pročelje [7] 
Na istočnom pročelju kule, osnovni elementi prizemlja i 1 . kata su isti (ulazni portal, monofora s gotičkim lukom i klupicom na konzolama). $\mathrm{Na}$ snimku D se dobro prepoznaje dozidavanje zida, što ukazuje na naknadno dodavanje portala oba kata u postojeći zid. Na 2. katu kule u svim snimcima je prikazana rozeta. Na snimku A su uz ovaj element prikazani sporedni otvori koji se ne vide na drugim snimcima (na snimku D se vide mogući tragovi). Istočni zid uz kulu je u snimku A viši, a u snimcima C i D niži. Iznad krova je u snimku A prikazan Bazilisk (metalni vjetrokaz u obliku Baziliska), koji više nije prikazan u drugim snimcima.

Zapadno pročelje kule je doživjelo još veće promjene - na 1. katu na snimku A prikazani je portal oblikom sličan istočnom portalu, ali je nacrtan kao da je od opeke. Na snimku C ovaj portal je zamijenjen pravokutnim otvorom (vrata), a takav otvor ostaje i na snimku D (gdje je vidljiv i rasteretni luk). U snimku A sjeverno od portala je prikazan mali otvor, koji nije vidljiv u snimcima C i D. Južno od portala (snimak A) je veći zazidani otvor (s oznakom „zazidano“) te iznad 1 mali otvor. Na 2. katu je u svim snimcima prikazana rozeta, a snimak D prikazuje i dva (zazidana) otvora sa obje strane rozete.

Razlike u prikazima, koje se ne mogu smatrati izmjenama u konstrukciji već razlike u snimcima, su (između ostalog): bolja definicija materijala u snimku D (npr. kod nacrta portala: tekstura zidova - mogu se bolje pratiti podaci o razvoju zgrade), oblik konzola, dimenzije... Razlika između snimaka C i D je minimalna u smjeru zapad-istok, a znatno veća u smjeru sjever-jug (čak $45 \mathrm{~cm}$ ). Za neke elemente (pogotovo manje otvore ili utore) se na različitim prikazima ne može protumačiti jesu li izmijenjeni radovima na Kaštelu ili su karakteristika prikaza (npr. nisu smatrani važnima za prikaz). Nema značajnih odstupanja u dimenzijama s obzirom na vrste snimka. Snimak B ne daje usporedive nacrte. U svim snimcima prikazana je i pomoćna građevina (ostaci) s južne strane kule, ali je, s obzirom na manjkavost izvedbene dokumentacije o intervencijama, teško procijeniti koliko su promjene u prikazima linije krova i otvora rezultat intervencija, a koliko karakteristika prikaza.

\subsection{Istočni zid}

Najznačajnija razlika u prikazu istočnog zida kompleksa (Slika 6) je različita visina zida koja se mijenja od snimka A do snimka C. U snimcima A, C i D, istočni zid djeluje jednak do otprilike $2 / 3$ visine, nakon čega se uočavaju promjene - npr. neki veći otvori (snimak A) su danas uobličeni u puškarnice, pojavljuju se i puškarnice koje nisu označene na snimku A (snimci C i D). Dorađen djeluje i sjeverni dio zida (snimak C i D). Dio otvora se i danas prepoznaje ili se može zaključiti koji radovi su rađeni - većinom se radi o radovima dozidavanja većih otvora u puškarnice. 
Posebno je značajna redefinicija zida u blizini Sjeveroistočne kule (od snimka C zid je viši). Osim toga, u odnosu na snimak A, sjeverni dio zida je danas više otkopan. S dvorišne strane se uočavaju promjene na zidu, pogotovo u gornjem dijelu, koje odgovaraju promjenama na istočnom pročelju. Ne prepoznaju se ležišta za konzole navedena u snimku A, a niti jesu li za sadašnji ophod korišteni postojeći ili novi otvori. U snimku D je u središnjem dijelu zida (s dvorišne strane) uočljiv reljef amblema obitelji Nugent.

Zbog većih pomaka u nacrtima nije moguće u potpunosti preklopiti snimke, a posebno su veliki pomaci snimka A u višim dijelovima kompleksa. Preklapanja su otežana i zbog različitih donjih i gornjih kota zida radi izmjena na terenu te izmjena u otvorima ili prikazu otvora. Snimak B ne daje usporedive nacrte.

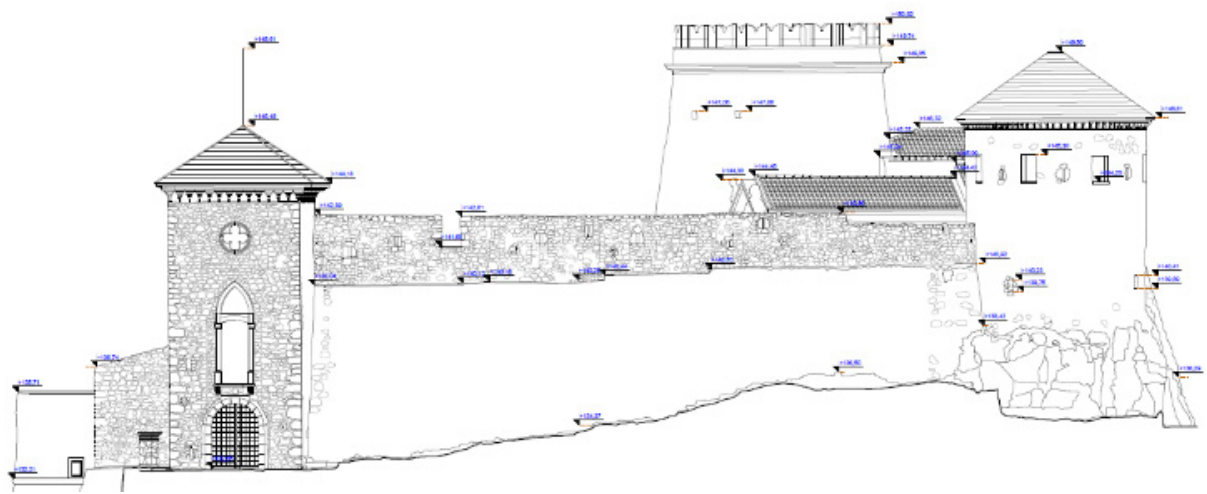

Slika 6. Istočni zid (povezuje Ulaznu i Sjeveroistočnu kulu). U drugom planu: Južna kula (lijevo), Rimska kula, krov Mauzoleja (centralno) i Sjevernog dijela [7]

\subsection{Mauzolej, sjeverni dio kompleksa i sjeverni zid}

Prostor Mauzoleja (Slika 7) je prikazan u svim snimcima, a osnovna razlika je u tome što su u snimku A ucrtana 3 objekta unutar tlocrta (mjesta sarkofaga) kojih u naknadnim snimcima nema, u nacrtima snimka B je dan projekt uređenja te je detaljno dan snimak krovišta koje je danas nedostupno. Zabat Mauzoleja je istaknut u odnosu na pokrov, što je zanimljiv detalj. Na zabatu su postavljene ležeće skulpture. Sa sjeverne strane Mauzoleja nalazi se prostor ophoda na dvije etaže (prizemlje i kat) uz sjeverni zid, danas ugostiteljske namjene. 


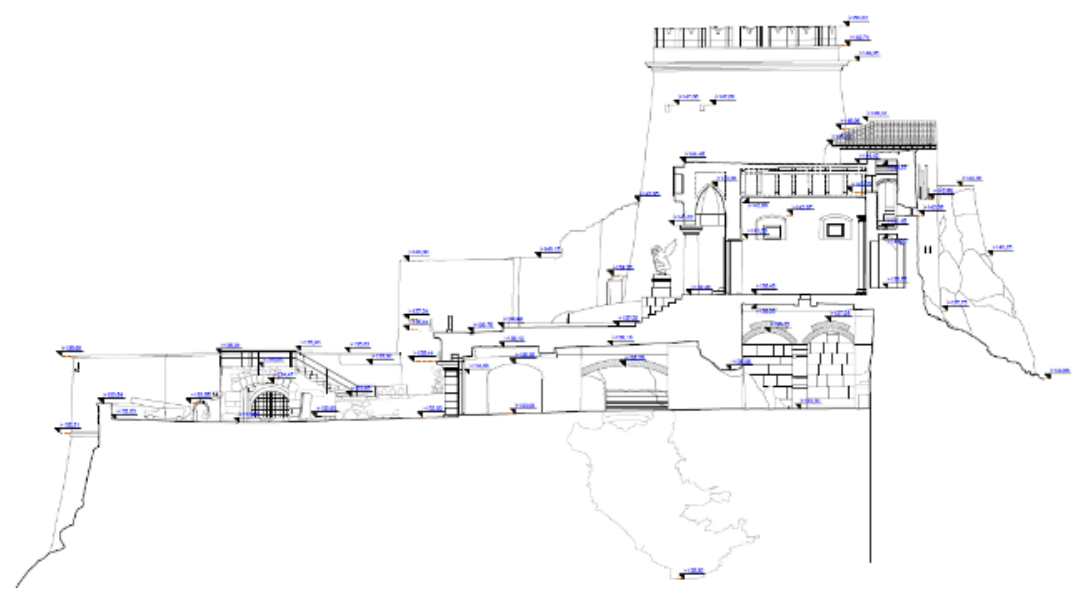

Slika 7. Presjek kroz Kriptu (u središnjoj razini), spilju (ispod Kripte), Mauzolej i sjeverni dio (viša razina) te pogled prema Rimskoj kuli [7]

Razlike u snimku A i C (i D), u zapadnom i centralom dijelu u skladu su s projektom prenamjene (prenamjena ophoda u prizemlju u kuhinju i servisne namjene). Na zapadu sjevernog dijela, u prizemlju, u snimku A je prikazan prolaz prema Zapadnom dijelu, a danas su tu smještene sanitarije i zid te se ovaj prolaz ne može prepoznati (snimak C i D). Na katu su, u snimcima, različito prikazani manji otvori, ali snimci C i D prikazuju prozorski otvor Mauzolej-hodnik.

Snimci A i C ne prikazuju teksturu zida, dok su na snimku D prikazani materijali (lukovi prizemlja od opeke, kutni elementi zidova iz većeg kamenja i ispune od manjeg kamenja, linearni vijenac između 2 etaže, ispuna ograde od sitnijeg ziđa). Iznad toga su prikazani stupovi koji nose krovište, a vidljivo je da zid ( u snimku D) uz Mauzolej završava stupom (na mjestu oštećenja iz snimka C). Postoje određene izmjene u otvorima na sjevernom zidu između snimaka C i D, posebno uz Sjeveroistočnu kulu.

Sjeverni zid (Slike 8, 9, 10, 11, 12) je po prvi puta snimljen u sklopu snimka D, a predstavlja izuzetno značajni izvor podataka o evoluciji Gradine jer nije srušen u potresu te nije značajno prepravljan u 20. stoljeću. Sastoji se od dvije glavne cjeline - od Sjeveroistočne kule do Rimske kule te od Rimske kule do kraja zapadnog dijela. Zid se nastavlja na prirodne stijene, tako da donja kota zida varira otprilike $6 \mathrm{~m}$ (baza je niža na zapadu, a najviša u središnjem dijelu te kod Rimske kule gdje stijene dosežu do same terase ulaza u Rimsku kulu). Nacrti arhitektonskog snimka rađeni su prema podlogama izvedenim iz oblaka točaka te brojnim fotografijama bespilotnom letjelicom i 3D laserskim skenerom kako bi se materijalni tragovi izmjena i oštećenja čim bolje utvrdili i unijeli u snimak. 


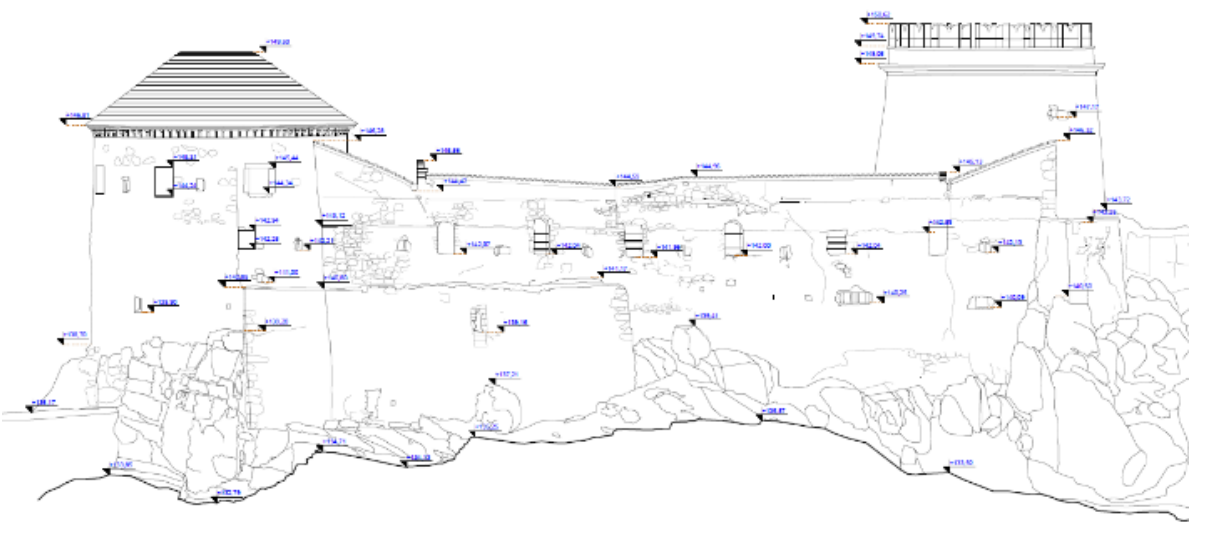

Slika 8. Sjeverni zid - uz centralni dio kompleksa. Lijevo: Sjeveroistočna kula, desno: Rimska kula [7]

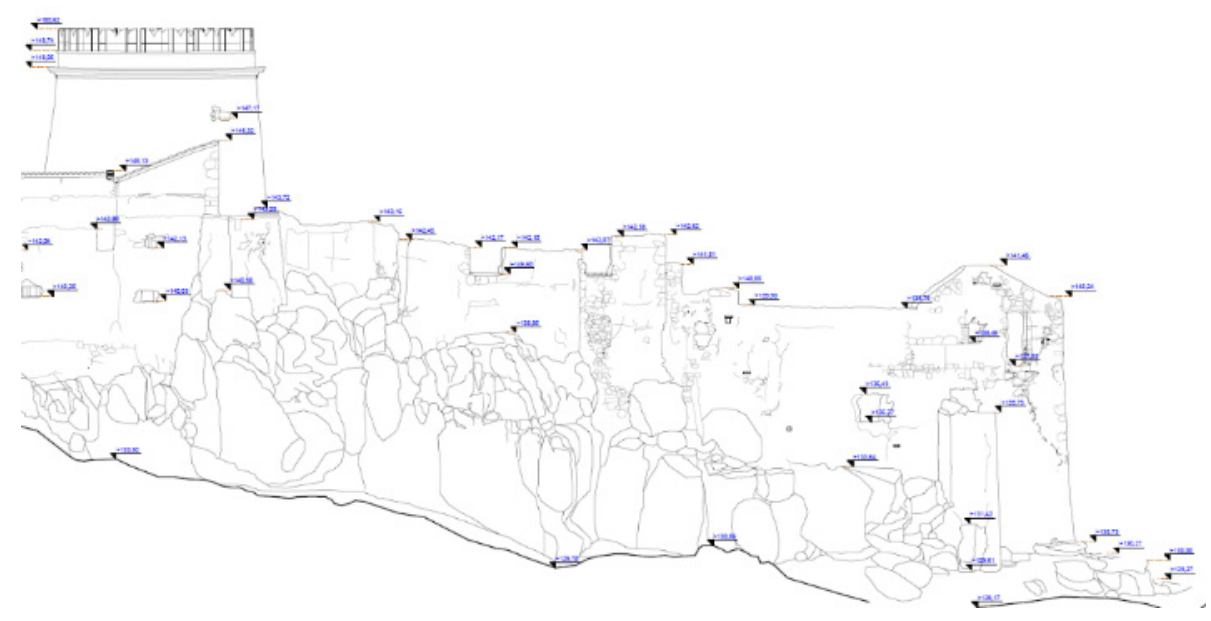

Slika 9. Sjeverni zid - uz Zapadni/stambeni dio kompleksa [7]

Uz Sjeveroistočnu kulu, sjeverni zid (s krovom) počinje uz vijenac kule na koti 146,45 m, a zatim se spušta i prati hodnik (ophod) uz sjeverni zid. U snimku D je prikazana terasa prema Rimskoj kuli (npr. vide se ograda terase, ulaz u sjeverni dio sa spuštenim lukom od opeke, linija oštećenja ili dozidavanja, ulaz u Rimsku kulu). Zid je najveće širine uz Sjeveroistočnu kulu, a dijelom i obuhvaća kulu (pri dnu). Ovaj dio zida se proteže zapadno od kule još $15 \mathrm{~m}$, a vidljivi su jedan otvor uz samo dno te jedan otvor $2 \mathrm{~m}$ iznad dna. Zid je tu visok oko $4 \mathrm{~m}$, a nakon toga se spaja s ostatkom zida koji se proteže od SI kule do Rimske kule. Može se primijetiti da je zid 


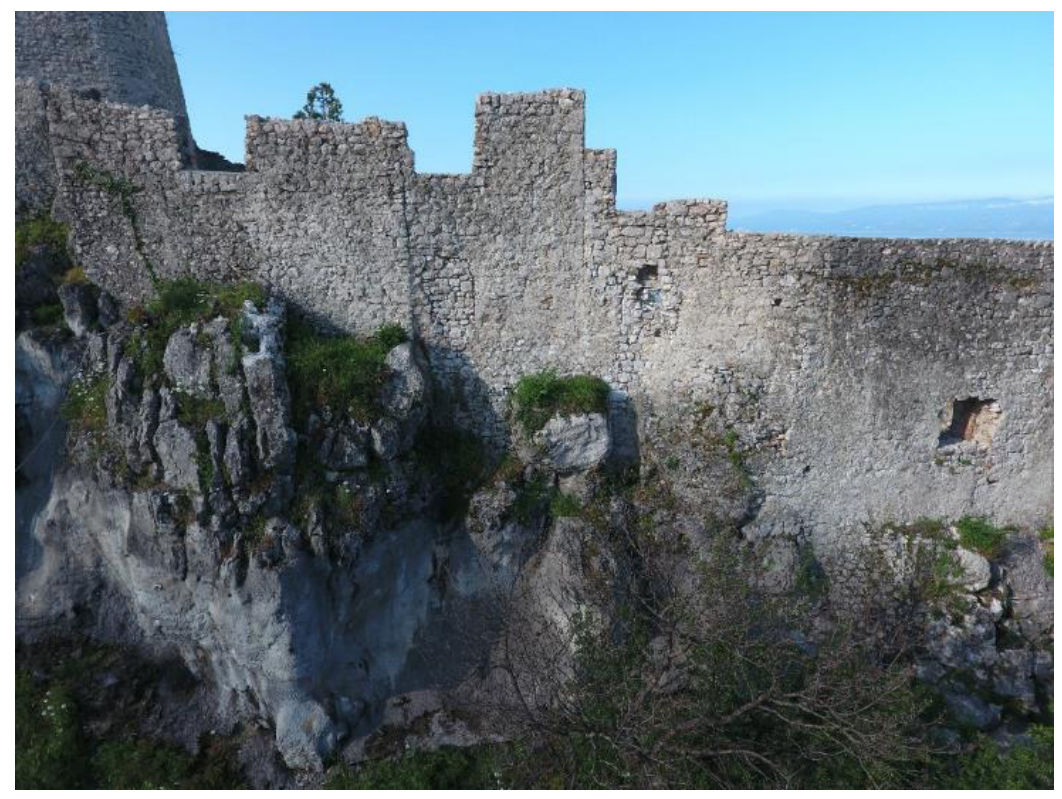

Slika 10. Sjeverni zid - uz Zapadni/stambeni dio kompleksa [7]

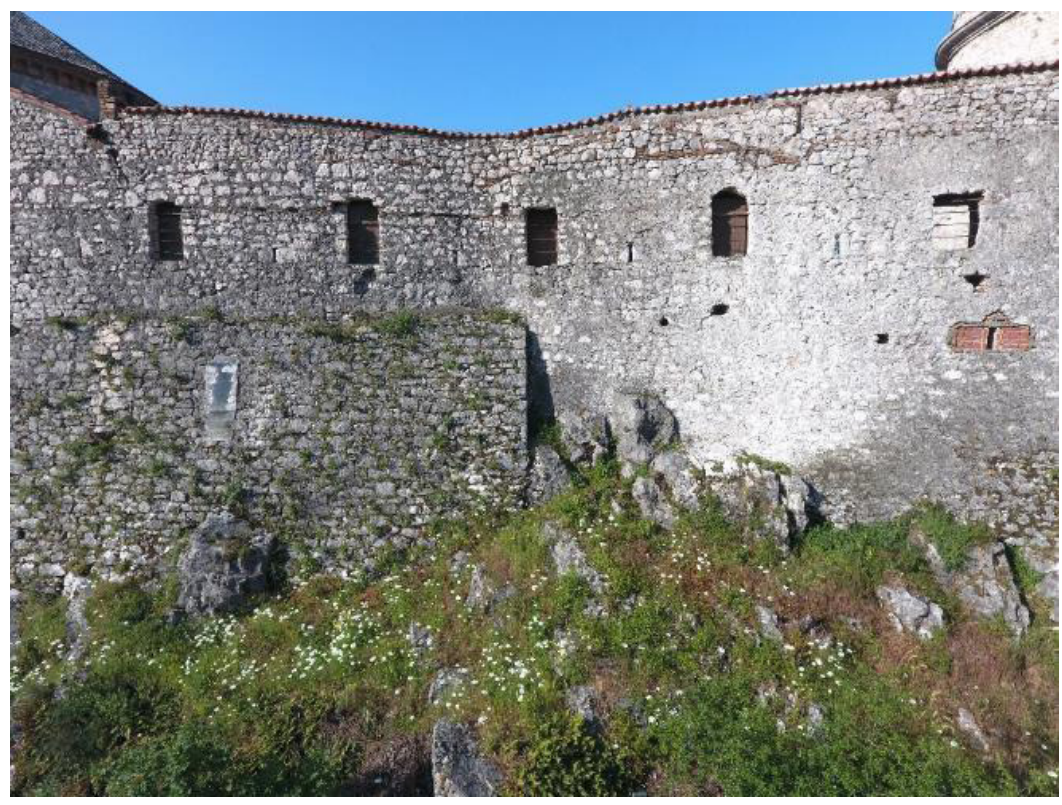

Slika 11. Sjeverni zid - uz Zapadni/stambeni dio kompleksa [7] 


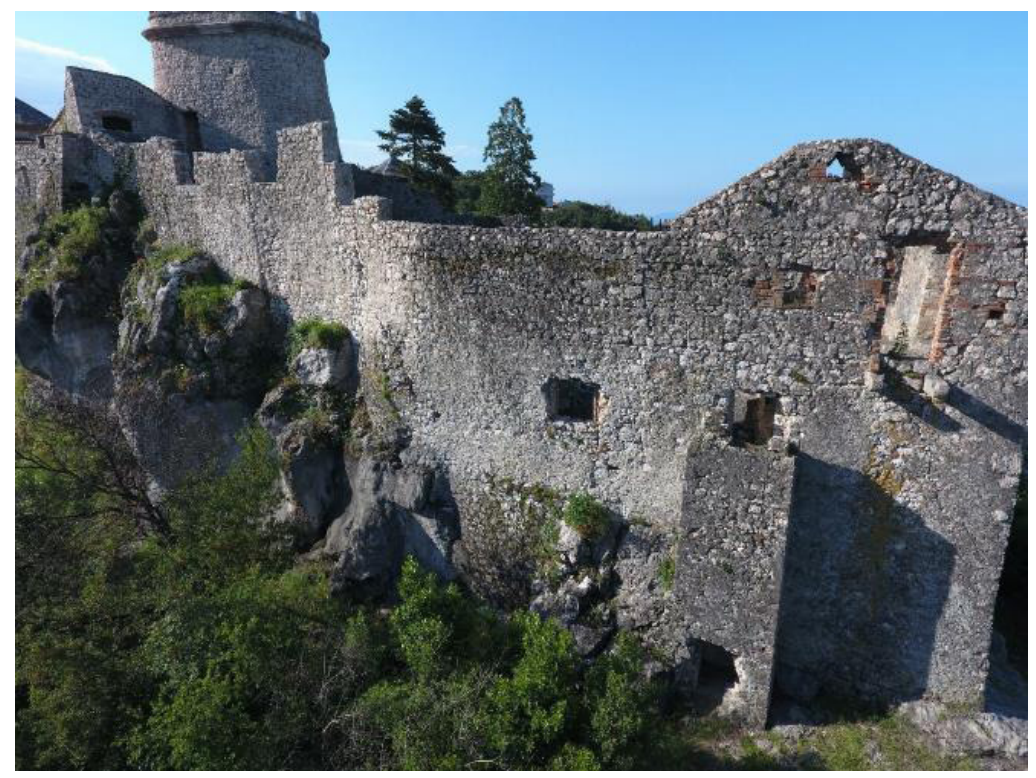

Slika 12. Sjeverni zid - uz Zapadni/stambeni dio kompleksa [7]

doživio nadogradnju od razine gornjeg dijela današnjih otvora na katu galerije te su prepoznatljive dvije etaže ophoda zida. U donjem dijelu zida vidljive su puškarnice, ali se vide i naznake manjih dorada zida. Na razini kata se vide tragovi većih preinaka. Uz Sjeveroistočnu kulu se prepoznaje zatvaranje većeg otvora nepravilnog oblika te prepravljanje nekoliko manjih otvora. Pri razini donje kote današnjih prozora nalaze se (između prozora) puškarnice. Postoje tragovi nekoliko prijašnjih otvora 80 -ak $\mathrm{cm}$ ispod današnje razine prozora (što upućuje na to da su se tu nekoć nalazila vrata).

Lukovi iznad današnjih otvora nalaze se u dograđenom dijelu $u$ kojem se također mogu prepoznati dvije faze. U prvoj fazi nadograđen je zid u visini od $1 \mathrm{~m}$ iznad prozora, a karakterističan je trag krova koji je bio postavljen iznad središnjeg dijela kompleksa (u smjeru kao danas Mauzolej), što upućuje na to da je postojala jedna centralna građevina koja je tada natkrivenim ophodima bila povezana s kulama na obje strane. U drugoj fazi nadogradnje formirane su današnje krovne plohe (koje se uzdižu prema kulama prateći stubišta) i gornji dijelovi prozora. Prisutni su i elementi učvršćenja konstrukcije (metalne zatege). Uz Rimsku kulu zid postaje ograda terase (prisutna su velika oštećenja). Prema zapadu, zid zatvara zapadni (stambeni dio) Kaštela.

U zapadnom dijelu (Slika 10), gledano od Rimske kule prema zapadu, mogu se prepoznati najmanje četiri različita dijela. Prvi dio je jako oštećen, 
visine do 3m, a vidljivi su i tragovi otvora (vjerojatno prozora). Drugi dio (Slika 11) je niži, s vidljivim otvorom te tragovima otvora koji se nalaze u razini s nižim tragovima u središnjem dijelu. Iduća zona zida prema zapadu je jako oštećena, a karakterizira je ostatak otvora ispod kojeg nalazimo tragove moguće preinake (vrata) te moguće tragove drugog otvora direktno ispod toga. U najzapadnijem dijelu zida (Slika 12) nalazimo velika oštećenja i moguće tragove, a zid završava zabatom s vratima, balkonskim konzolama, prozorom, otvorom za sljemenu gredu, tragovima prozora i prostorom za stubište.

\subsection{Rimska kula, SI kula, Južna kula}

Rimska kula (Slike 8, 9, 13) je središnji dio kompleksa. Najniža etaža je na $141,1 \mathrm{~m}$, a najviši ophod na $149,3 \mathrm{~m}$. Snimak A ne prikazuje precizne nacrte kule, ali se naknadnim snimcima ne mogu zamijetiti veće razlike. Snimak A također prikazuje osnovne mjere kule, ali npr. ne prikazuje prostoriju u dnu kule.

U odnosu na snimak A, u snimcima C i D Sjeveroistočne kule (Slike 8, 13), nalazimo u prizemlju 2 puškarnice te novo stubište, na katu puškarnicu prema sjeveru, na 2 . katu 5 prozora i 4 puškarnice.

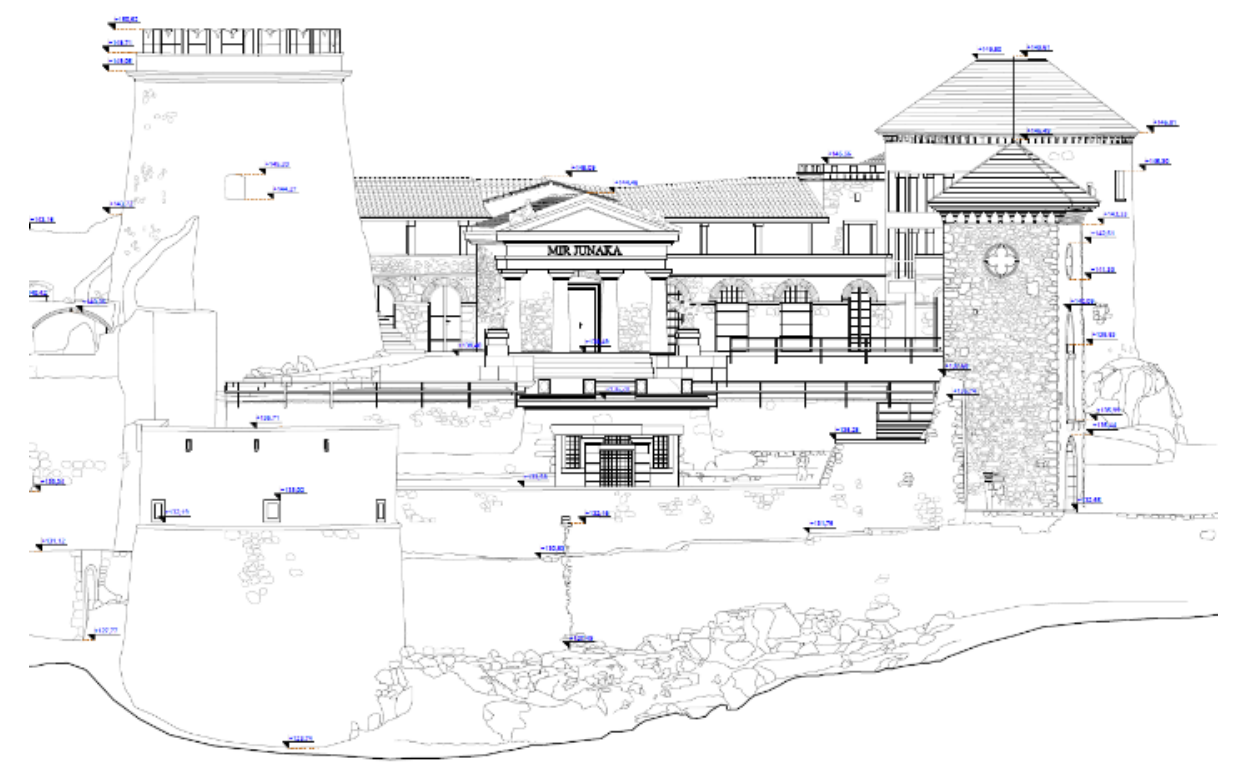

Slika 13. Pogled s južne strane - lijevo dolje: Južna kula, lijevo gore: Rimska kula, središnji dio: ulaz u Kriptu, Mauzolej, sjeverni dio, desno: Ulazna kula, Sjeveroistočna kula [7] 
Prikaz Južne kule (Slike 6, 13) u snimku A je vrlo precizan, osim položaja parapeta, a vanjski zid je prikazan nešto kraći. I snimci B i C relativno precizno prikazuju ovu kulu. U snimku D nema značajnijih razlika osim što su utvrđene precizne visinske kote poda i drugih elemenata, što je omogućeno korištenjem 3D laserskog snimanja.

\subsection{Zapadni/stambeni dio kompleksa}

Snimkom D je prvi puta detaljno snimljen zapadni (stambeni) dio kompleksa (Slike 9, 10, 12, 14). Prema snimku A, moguće je da je ovaj dio kompleksa bio spojen s centralnim dijelom, osim u dijelu dvorišta (kao danas) i prolazom sjeverno od Rimske kule. Snimak A prikazuje situacijski snimak, snimak B ne daje usporedivi snimak, a u snimku C su prikazane osnovne linije zidova i otvora. Također, kako je prvi puta snimljen sjeverni zid, po prvi puta je moguće usporediti prostorne podatke koje rezultiraju iz ova 2 dijela snimka. Danas su u ovom dijelu većinom izloženi (poslagani na terenu) ostaci lapida iz kolekcije Nugent, a u snimku D je utvrđena i njihova pozicija.

Snimak D daje detaljne kote i pozicije sadašnjeg stanja ostataka Zapadnog dijela. Teško je iščitati moguće povijesno stanje iako postoje brojni tragovi (otvori prozora, cjeloviti ili djelomični, ležišta greda, promjene u debljini zida...). Jasno se uočavaju gornje etaže, posebno u zapadnom vrhu (Zona 1, Slika 14, Slika 15). Kako zone uz zidine zapad imaju relativno konstantnu širinu, moguće je zaključiti da su se u tom dijelu nalazile prostorije na tri etaže. Iako je stambeni dio dijelom urušen, a dijelom još uvijek ukopan, može se uočiti nekoliko mogućih jedinica (Slika 14).

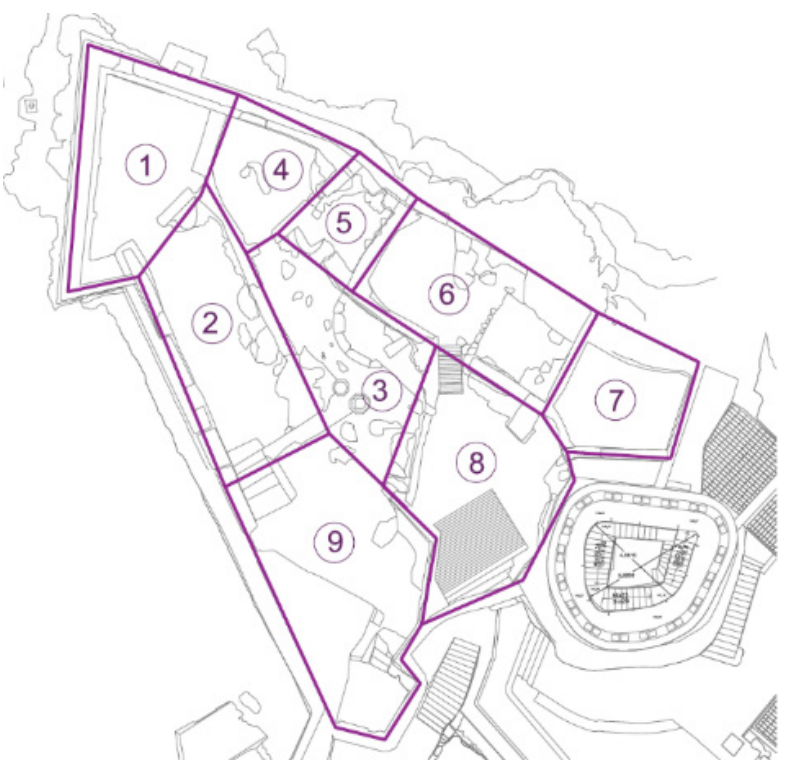

Slika 14. Zone unutar stambenog (zapadnog) dijela 


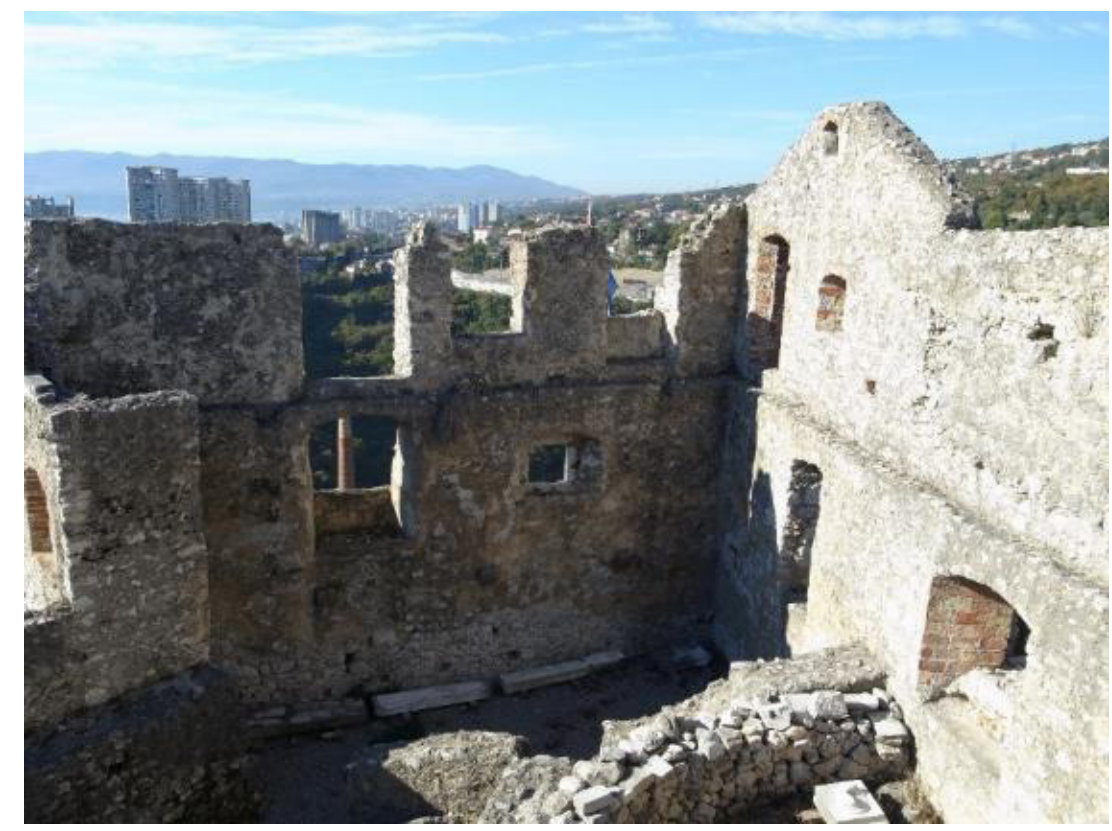

Slika 15. Zapadni/stambeni dio - pogled prema zapadu [7]

Prema ostacima zidova (konzole u zidovima, promjena debljine zidova, ležaji stropnih greda, otvori prozora i vrata...), osnovni prijelazi etaža su na razini 132,0 m, 134,20 m i 137,10 m, 139,9 m (na što upućuju i tragovi u konstrukciji sjevernog zida). Prema ostacima i tragovima, moguće je pretpostaviti da se donja etaža nalazila na koti (otprilike) 132,0 m (ovoj razini odgovaraju položaji prozora na južnom zidu, otvori i ležajevi stropnih greda na zapadnom zidu). Isti tragovi upućuju na višu etažu na razini $134,2 \mathrm{~m}$ (Slika 16).

Na snimku D se mogu prepoznati otvori u sjevernom zidu, niz ležaja stropnih greda i linija krovišta (iznad koje je naknadno dozidana etaža), te lučna konstrukcija gospodarstva - peći (Zone 1,4-8). Zanimljivo je da se pod etaže stambenog dijela (1. kat zapad) te kote sjevernih dijelova sve do Rimske kule nalaze na istoj razini $(137,1 \mathrm{~m})$, što upućuje na mogućnost da se možda radilo o jedinstvenoj komunikacijsko-funkcionalnoj razini (na ovoj razini se nalaze i ostaci peći te prolaz do središnjeg dijela uz južni dio Rimske kule).

Prema tragovima na sjevernom zidu (ležajevi greda, konzole), gornje etaže su se nastavljale u istim razinama uz sjeverni zid - kota 137,1 m (ostaju i ostaci krovišta u zoni 6), a nakon toga je u zonama 4, 5, 6 i 7 dignuta najmanje jedna etaža - od kote 139,9 m (do kote $143 \mathrm{~m}$ ), što odgovara liniji nadogradnje sjevernog zida koja se vidi u sjevernom pročelju (od gornjeg dijela današnjih prozora ophoda). 

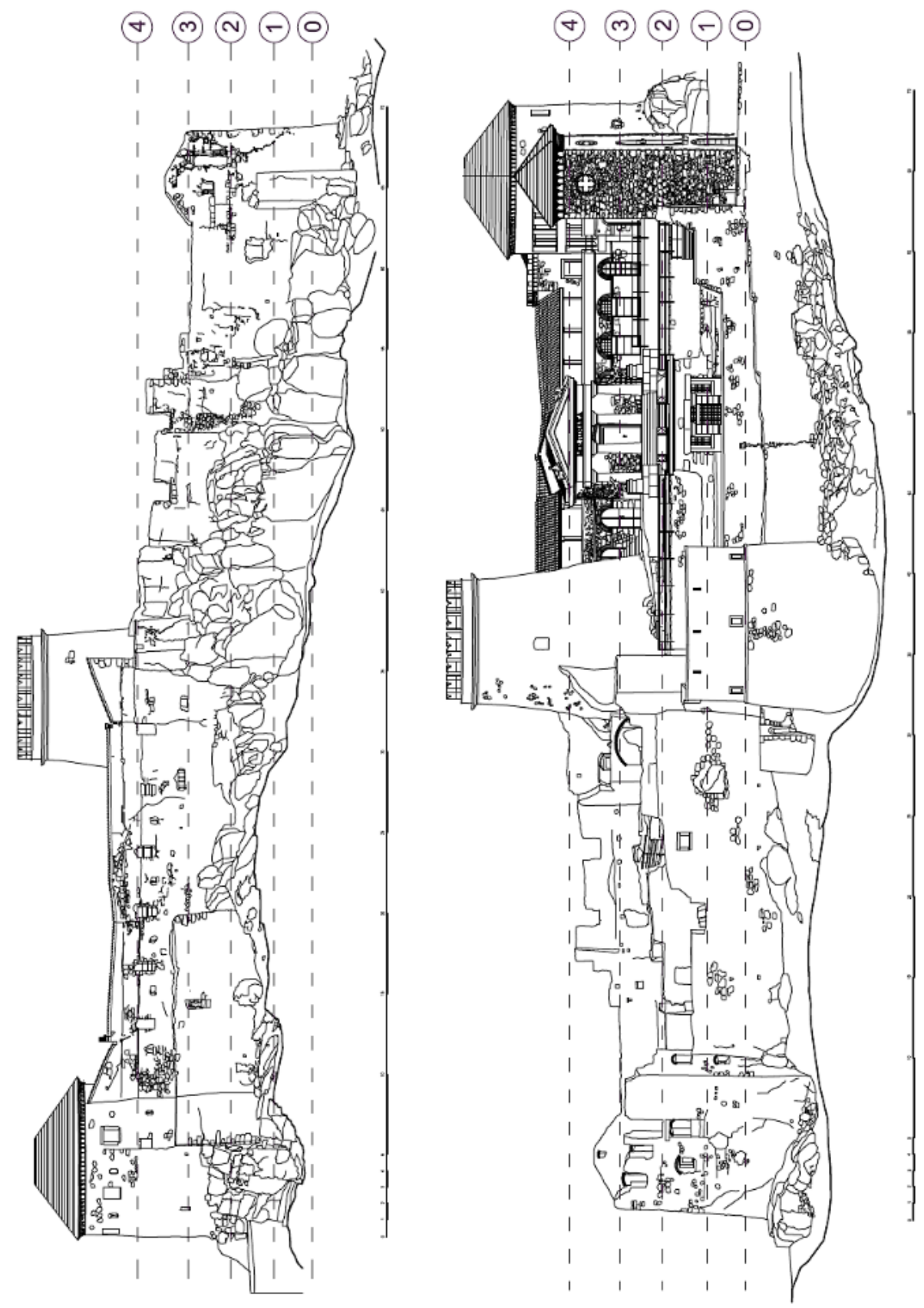

Slika 16. Prijedlog etaža (funkcionalnih razina) prema tragovima na kompleksu, podloga [7] 
Zona 1 čini vrh trokutnog bastiona, a sa zapada je zatvorena zidom debljine 1,2 m. Prema sjevernoj strani je istak. Širina prostora varira između $3 \mathrm{~m}$ i 4,4 m. Ovaj prostor je povezan s prostorom zone 2 prolazom širine 1,6 m. Mogu se prepoznati tri etaže od kojih jedna djelomično zakopana. U ovoj zoni se također vidi zabatni završetak zida te dodatni uski volumen čiji zid ima veliko oštećenje u prizemlju, a proteže se kroz dvije etaže. Na katu su vidljivi otvori prozora i vrata ispod kojih se nalaze konzole (kao za balkon). $\mathrm{Na}$ vrhu ovog zabatnog zida se vidi otvor za sljemenu gredu. Na koti $137 \mathrm{~m}$ prolazi reška koja odvaja 2 vrste konstrukcije pa se gornji dio zida, zajedno sa otvorima, čini naknadno dodanim, a primjećuju se i reška na koti 138,46 m te vertikalna reška između dijela zida sa zabatom i zida prema istoku. Otvori prozora, vrata i ležaja sljemene grede su definirani opekom, vjerojatno kasnije, a uočavaju se i pukotine zida od balkonskih konzola do ruba zabata (zapad). Posebno je zanimljivo postavljanje istaknutog volumena na nižem dijelu terena te balkona koji nisu tipični za obrambene strukture.

Zona 2 se nalazi uz zapadni zid. Širina prostora zone varira od 3,5 $\mathrm{m}$ do 4,2 m. Sjeveroistočni rub je nepravilan, a jugozapadni čine zidine debljine 1,6 m. U južnom dijelu se uočava prolaz prema višem centralnom dijelu. U južnom dijelu ove zone se mogu prepoznati otvori na različitim visinama.

Centralno u ovom dijelu, na koti $133,5 \mathrm{~m}$, prostire se plato ujednačene visine duž zona (zona 3). Konstrukcije zone 2 i zone 8 je vjerojatno povezivao luk (postoje ostaci). Prema nepravilnom obliku središnje zone može se pretpostaviti da je bila nepokrivena. Preporuča se usporedba s poznatim prikazima i trodimenzionalna rekonstrukcija.

Zone 4-5-6-7 se nastavljaju uzduž sjevernog zida te su, iako na prvi pogled djeluju kao različiti volumeni, prema tragovima u zidovima (opisani iznad) mogle formirati volumen s jedinstvenim etažama. Ovaj dio je izuzetno prekrajan, tako da se vide zatvarani otvori, tragovi krova (okomiti na sjeverni zid) te nadozidavanja. Nastavno na zonu 1, na snimku D se mogu prepoznati: prostor veličine otprilike $4 \mathrm{~m}$ x $6 \mathrm{~m}$ sa zazidanim otvorom na sjevernom zidu (zona 4), prostor veličine $3 \mathrm{~m}$ x $3 \mathrm{~m}$ s otvorima na dvije strane (prema centralnom platou te tragovima zazidanih otvora na sjevernom zidu, zona 5), prostor dugačak oko $10 \mathrm{~m}$ koji se sastoji od dva dijela, dužine 6,5 m (od kote $138 \mathrm{~m}$ do 142,45 m) i $4 \mathrm{~m}$ (od kota oko 137 $\mathrm{m}$ do $142,6 \mathrm{~m}$ ) s ostacima dva prozora na pretpostavljenoj razini 3. kata i zazidanim otvorom na razini 2 . kata (zona 6), prostor veličine $5,5 \mathrm{~m} \mathrm{x} \mathrm{3,5} \mathrm{m}$ (zona 7) s tragovima zazidavanja otvora ili oštećenja. Na koti zone 7 nalaze se prostori Rimske kule i vanjski podest. Ove zone djeluju ujednačene u funkcijama (zid s prozorskim otvorima), ali su odvojene prekidima u konstrukciji. Bez dodatnih istraživanja (i posebno bližeg pristupa) nije moguće reći koji dijelovi čine istu konstrukcijsku fazu te koji su dijelovi stariji. 
U zoni 8 se uz Rimsku kulu nalaze ostaci ognjišta i peći, prolaz prema središnjem dijelu kompleksa i cisterna, danas pokrivena platformom. $\mathrm{Na}$ snimku D se uočava ostatak zida koji uz Rimsku kulu ima istu visinu kao i sjeverni zid. Zona 9 predstavlja zonu ulaska u zapadni dio s južne strane, a prema ostacima ležaja greda i konzola u zidovima, može se pretpostaviti da je i ovaj dio bio uređen kao ophod (na jedinstvenoj razini kao 1. kat stambenog dijela).

Dok je snimkom D postignuta prva precizna izmjera ovog dijela kompleksa, zanimljivo je da je ovaj dio prikazan u snimku C, ali s većim odstupanjima. Tako nisu prikazani otvori na jugozapadnom dijelu kao dva prozora i jedna vrata nego kao jedan prozor i jedan veći poludefinirani otvor.

\subsection{Kripta i spilja}

U snimku D laserskim snimanjem je snimljena kripta, a po prvi puta je snimljena i spilja (Slika 7).

Položaj i dimenzije kripte su u snimku A u 1:100 preciznije prikazani nego u nacrtu u 1:50, a posebno se to odnosi na kutove. Kripta se sastoji od tri prostorije (ulazne, prolaza i prostorije ispod Mauzoleja), a iz prolaza se može pristupiti spilji. Prva prostorija je u snimku A kraća $50 \mathrm{~cm}$ nego u snimku D, a prirodna stijena počinje $2,5 \mathrm{~m}$ ranije nego u snimku $\mathrm{D}$. Pomak finalne prostorije je do 1,6 m (pa i 1,9 m u nekim dijelovima), što prati rotaciju snimka u tlocrtu. U snimku A se pojavljuje i visinski pomak u odnosu na sadašnji snimak. Zanimljivo da su početni dijelovi snimljeni u snimku A s pomakom od više od $50 \mathrm{~cm}$, uključujući i svijetli otvor lukova. S obzirom da ove dimenzije nije teško izmjeriti, pretpostavlja se da izmjera ovog prostora možda nije bila prioritet. Najveće razlike su u završnom dijelu kripte, gdje se, većinom zbog pomaka u kutu snimka od $14^{\circ}$, dešavaju pomaci točaka i do $1,6 \mathrm{~m}$ pa kripta djeluje kraća u svom centralnom dijelu $25-90 \mathrm{~cm}$.

\section{Zaključak}

3D snimkom laserskim skenerom dobiven je oblak točaka koji jednoznačno pozicionira točke u prostoru pa se, neovisno o vrsti podloga koje je potrebno napraviti, ne događa različitost pozicija i dimenzija. Zbog toga se ne događa pomak dijelova nacrta ili različitih nacrta jedan u odnosu na drugi. Posebno je to važno kod kutova, što je tradicionalnim snimkom bilo teško postići i gdje su kod tradicionalnih snimaka očite najveće greške (Slika 17). 


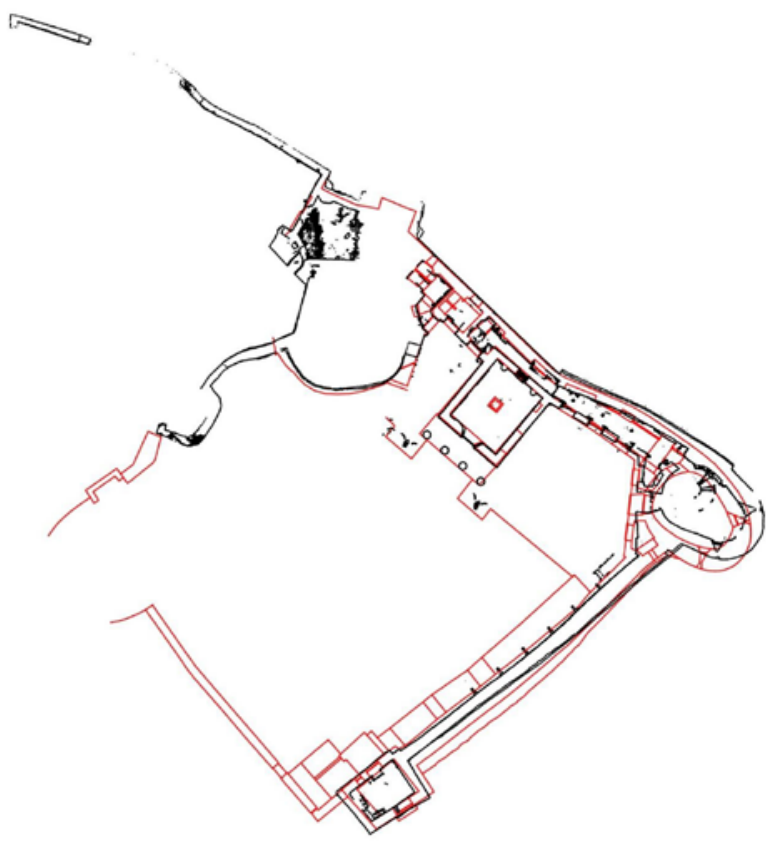

Slika 17. Kaštel Trsat, tlocrt na koti $+139,5 /+140$, usporedba snimka postojećeg stanja iz 1986. godine dobivenog klasičnim mjerenjem (crveno) i snimka iz 2016. godine dobivenog 3D snimanjem (crno) [7]

Iako je samo snimanje bilo napravljeno velikom rezolucijom, pri obradi podataka i slaganju oblaka točaka bilo je potrebno smanjiti rezoluciju zbog iznimne veličine objekta i količine podataka. Zbog toga se može zaključiti da lasersko snimanje za ovako velike komplekse još uvijek zahtijeva ili parcijalni pristup (po elementima kompleksa) ili ne daje detaljnost koji omogućava sam laserski skener. Također, snimanje bespilotnom letjelicom (iako omogućuje uvid u nepristupačne dijelove kompleksa) ne daje dovoljnu rezoluciju kako bi se mogle utvrditi točne stratigrafske jedinice i njihov međusobni odnos (npr. ne vidi se jasno naslanjanje morta na jednu ili drugu stranu između kamena) te kao takav ne može još zamijeniti osobni izvid (što npr. zahtijeva postavljanje skele) i klasičnu fotogrametriju (isti problem). Osim toga SfM model je dao manju točnost geometrije (što je problem samo po sebi), ali ujedno i privid točnosti, što povećava problem korištenja npr. kod izrade snimaka samo snimanjem bespilotnom letjelicom i izradom SfM modela bez mogućnosti usporedbe s laserskim snimkom, što je čest primjer u praksi. Ovaj problem će se vjerojatno riješiti razvojem tehnologije. Naime, veličina distorzija u SfM modelu je povezana s načinom rada (fotomodeliranje ravne površine pa stavljanje na model daje bolje rezultate, ali ovaj pristup nije jednostavan za veće elemente) i veličinom 
objekta (veći objekt/kompleks obično ima veće distorzije, što je primijećeno u ovom snimku, ali i u drugim znanstvenim radovima [15] i softwareima). $\mathrm{S}$ druge strane, prednost SfM modela je prvenstveno u jednostavnosti i brzini snimka, mogućnosti modeliranja prema povijesnim fotografijama (npr. kod objekata ili situacija koje više ne postoje, podvodnog snimanja, prezentacije javnosti. $[17,20,21]$ Kako se danas 3D modeli baštine sve više koriste u kombinaciji s drugim suvremenim tehnologijama (geoprostornim servisima kao što je GoogleEarth, video igrama, vizualizacijama, proširenoj stvarnosti, za projektiranje, održavanje i monitoring...), 3D modeli za baštinu bi trebali [21] imati sljedeće karakteristike: preciznost, prenosivost, niske troškove, brza usvajanje podataka i fleksibilnost. Tijekom snimanja Trsatske gradine snimanje je ispunilo samo neke od ovih kriterija. Lasersko skeniranje ispunjava skoro sve zahtijevane karakteristike osim troškova koji su vezani na samu cijenu instrumenta, softwarea, računala, ali i cijenu održavanja aparata. S druge strane snimanje dronom omogućuje sve ostale karakteristike osim preciznosti (barem zasad).

3D model izrađen u obliku oblaka točaka velika je i trajna baza podataka koja može služiti za izradu i drugih potrebnih nacrta. Kod snimaka izrađenih tradicionalnim metodama, elementi su prikazani samo u osnovnim linijama, dok se u novom snimku može ući u teksturu i detalje konstruktivnih elemenata jer se ručno, tradicionalnim snimkom, ne može prenijeti ista količina podataka. Osim toga, problem utvrđivanja visinskih kota kod snimaka klasičnom metodom riješen je 3D laserskim snimanjem. Točno pozicioniranje u prostoru horizontalno i vertikalno omogućava bolje sagledavanje smještaja različitih jedinica kompleksa te međusobne odnose.

Posebno je važno što su zapadni dio i sjeverni zid snimljeni i proučeni do ove detaljnosti po prvi puta, kao i spilja, istočno pročelje Mauzoleja i kuća Nugent.

Iako su zidovi kompleksa većinom prekriveni žbukom, a i često nije bilo moguće prići bliže nego što je napravljen snimak (visoke rezolucije) bespilotnom letjelicom, na zapadnom dijelu i sjevernom zidu mogu se uočiti različite faze gradnje, odnosno konstrukcijski prekidi i tragovi koji upućuju na puno veću raznovrsnost korištenja i preinaka nego što se može pretpostaviti za jedan obrambeni objekt.

Snimak D daje broje indikacije o višefaznom prekrojavanju Zapadnog dijela, posebno u visinu, ali i dodavanjem i prerađivanjem prostora i otvora, što se ne može pratiti niti iz povijesnih grafičkih prikaza gradine koji većinom prikazuju samo južno i jugozapadno pročelje kompleksa pa iz njih razvoj sjevernog i stambenog dijela ostaje upitan, a indicije daje tek sadašnji snimak sjevernog zida i zapadnog dijela.

Moguće je dijelom razaznati različite faze konstrukcije i oblika zgrada koje su činile ovaj dio kompleksa, ali je svakako preporučljivo izraditi 3D model mogućih faza razvoja kompleksa. Pomalo je iznenađujuće izuzetno 
dobro poklapanje tragova koji se mogu utvrditi u zapadnom dijelu i sjevernom zidu te poklapanje tragova na konstrukciji koji omogućavaju definiranje etaža, a što po prvi puta daje uvid u moguću prostornofunkcionalnu organizaciju zapadnog dijela sa središnjim trgom i dobrom povezanosti sa današnjim centralnim dijelom kompleksa. Također je zanimljivo da analiza mogućih etaža upućuje na tri glavne etaže kompleksa, što bi odgovaralo povijesnim prikazima iz 17. i 18. stoljeća, a što bi također bilo dobro istražiti usporedbom mogućeg 3D modela i povijesnih prikaza.

Zahvala. Prikazani rezultati proizašli su iz znanstvenog Istraživačkog projekta "Arhitektura Rijeke i riječke regije kao razvojni resurs" (voditeljica projekta izv. prof. dr. sc. Nana Palinić, dipl. ing. arh., projekt Sveučilišta u Rijeci. Ovaj je članak rezultat rada u okviru projekta Razvoj istraživačke infrastrukture na Kampusu Sveučilišta u Rijeci (RC.2.2.06-0001) koji je sufinanciran iz Europskog fonda za regionalni razvoj (EFRR) i Ministarstva znanosti, obrazovanja i sporta RH ("This work has been supported in part by Ministry of Science, Education and Sports of the Republic of Croatia under the project Research Infrastructure for Campus-based Laboratories at the University of Rijeka, number RC.2.2.06-0001. The Project has been co-funded by the European Fund for Regional Development (ERDF)").

\section{Literatura}

[1] Matejčić, R. (2007), Kako čitati grad : Rijeka jučer, danas. Rijeka: Adamić. 4. izdanje

[2] Glavinich, F. (1989), Historia tersattana: raccolta dalle antiche, e moderne historie, annali, e traditioni. Rijeka: Sveučilište Vladimir Bakarić : Naučna biblioteka, Historijski arhiv, Tiskara Rijeka; Zagreb : Sveučilišna naklada Liber. Originalno izdanje: Udine, Appresso Nicolo Schiratti, 1648.

[3] Antić, V. (uredio) (1982), Trsat od davnih do današnjih dana, Rijeka : Narodna čitaonica - Trsat

[4] Balabanić Fačini, M., Cvijetinović Starac, M. (2004) Trsatska gradina. Rijeka : Pomorski i povijesni muzej Hrvatskog primorja

[5] (1894) La colonna di Marengo nel castello di Tersatto, La varieta : la giornale per tutti, 13 (1894), 138

[6] Lukež, N. (2009) Trsatska gradina - arhitektonska i građevinska analiza, Završni rad, Sveučilišni preddiplomski studij Građevinarstva, Građevinski fakultet, Rijeka

[7] Palinić, N., Ružić, I., Matan, C., Kalajžić, D., Mrak, I., Peranić, M. (2016) Kaštel Trsat - snimak postojećeg stanja metodom 3D skeniranja, Rijeka, Sveučilište u Rijeci, Građevinski fakultet

[8] Ured ovlaštenog arhitekta Renato Cottiero, (2016) Kaštel Trsat, konzervatorska studija, Zagreb 
[9] Grad Rijeka, Gradsko vijeće (2013) Strategija kulturnog razvitka Grada Rijeke 2013.-2020.,https://www.rijeka.hr/wp-content/uploads/2013/04/ Strategija-kulturnog-razvitka-Grada-Rijeke-2013.-\%E2\%80\%93-2020.pdf, (pristup 22.12.2018.)

[10] Senjanović, Emili (1956) Snimak postojećeg stanja. Državni arhiv u Rijeci

[11] Uravić, M. (1986), Uprava za zaštitu kulturne baštine - Konzervatorski odjel u Rijeci

[12] Vukušić, Ž (2001), Trsatska gradina, studija postojećeg stanja, Uprava za zaštitu kulturne baštine - Konzervatorski odjel u Rijeci

[13] Docci, M., Maestri, D. (2009) Manuale di rilevamento architettonico e urbano. Bari: Laterza

[14] Mrak., I. (2013) „Metode izrade snimka postojećeg stanja - nastupno predavanje", Rijeka: Sveučilište u Rijeci, Građevinski fakultet, neobjavljeni materijal

[15] Historic England (2018) 3D Laser Scanning for Heritage: Advice and Guidance on the Use of Laser Scanning in Archaeology and Architecture. 3. izdanje. Swindon: Historic England

[16] Historic England (2017) Photogrammetric Applications for Cultural Heritage. Guidance for Good Practice. Swindon. Historic England

[17] McCarthy, J. (2014) Multi-image Photogrammetry as a Practical Tool for Cultural Heritage Survey and Community Engagement. Journal of Archaeological Science, 43, 2014, str. 175-185, ISSN 0305-4403, https://doi. org/10.1016/j.jas.2014.01.010.

[18] Waas, M., Zell, D. (2014) Practical 3D Photogrammetry for the Conservation and Documentation of Cultural Heritage. In Börner, W., Uhlirz, S. (ur.) Proceedings of the 18th International Conference on Cultural Heritage and New Technologies 2013 (CHNT 18, 2013). Vienna: Museen der Stadt Wien Stadtarchäologie

[19] Vidmar, K. (2016), Zgrada bivše rezidencije Nugent u sklopu Kaštela Trsat arhitektonski snimak postojećeg stanja metodom 3D skeniranja. Diplomski rad. Rijeka: Sveučilište u Rijeci, Građevinski fakultet u Rijeci

[20] Rinaudo, F. (2018) "Photogrammetry in Cultural Heritage: Is It Only SFM Software”, ISPRS Technical Commission II Symposium, http://www.isprs. org/tc2-symposium2018/images/ISPRS-Interview-Rinaudo.pdf (pristup 22.12.2018.)

[21] Remondino, F. (2011) Heritage Recording and 3D Modeling with Photogrammetry and 3D Scanning. Remote Sens. 2011, 3, 1104-1138; doi:10.3390/rs3061104 
